\title{
Comprehensive Research on Past and Future Therapeutic Strategies Devoted to Treatment of Amyotrophic Lateral Sclerosis
}

\author{
Belgin Sever ${ }^{1,2} \mathbb{D}$, Halilibrahim Ciftci ${ }^{2,3,4}{ }^{\mathbb{D}}$, Hasan DeMirci ${ }^{4} \mathbb{D}^{\text {, Hilal Sever }}{ }^{5}$, Firdevs Ocak ${ }^{6}$, Burak Yulug ${ }^{7}$ \\ Hiroshi Tateishi $^{2}$ (D), Takahisa Tateishi ${ }^{8}$, Masami Otsuka ${ }^{2,3}$, Mikako Fujita ${ }^{2, *(D)}$ and Ayşe Nazlı Başak ${ }^{9, *(D)}$
}

\section{check for}

updates

Citation: Sever, B.; Ciftci, H.;

DeMirci, H.; Sever, H.; Ocak, F.;

Yulug, B.; Tateishi, H.; Tateishi, T.; Otsuka, M.; Fujita, M.; et al.

Comprehensive Research on Past and

Future Therapeutic Strategies

Devoted to Treatment of

Amyotrophic Lateral Sclerosis. Int. J.

Mol. Sci. 2022, 23, 2400. https://

doi.org/10.3390/ijms23052400

Academic Editor: Bruno Bonetti

Received: 16 January 2022

Accepted: 8 February 2022

Published: 22 February 2022

Publisher's Note: MDPI stays neutral with regard to jurisdictional claims in published maps and institutional affiliations.

Copyright: (C) 2022 by the authors. Licensee MDPI, Basel, Switzerland. This article is an open access article distributed under the terms and conditions of the Creative Commons Attribution (CC BY) license (https:// creativecommons.org/licenses/by/ $4.0 /)$.
1 Department of Pharmaceutical Chemistry, Faculty of Pharmacy, Anadolu University, Eskisehir 26470, Turkey; belginsever@anadolu.edu.tr

2 Medicinal and Biological Chemistry Science Farm Joint Research Laboratory, Faculty of Life Sciences, Kumamoto University, Kumamoto 862-0973, Japan; hiciftci@kumamoto-u.ac.jp (H.C.); htateishi@kumamoto-u.ac.jp (H.T.); motsuka@gpo.kumamoto-u.ac.jp (M.O.)

3 Department of Drug Discovery, Science Farm Ltd., Kumamoto 862-0976, Japan

4 Department of Molecular Biology and Genetics, Koc University, Istanbul 34450, Turkey; hdemirci@ku.edu.tr

5 Ministry of Health, Istanbul Training and Research Hospital, Physical Medicine and Rehabilitation Clinic, Istanbul 34098, Turkey; severhil@gmail.com

6 Faculty of Medicine, Kocaeli University, Kocaeli 41001, Turkey; 200601195@kocaeli.edu.tr

7 Department of Neurology and Neuroscience, Faculty of Medicine, Alaaddin Keykubat University, Alanya 07425, Turkey; burak.yulug@alanya.edu.tr

8 Division of Respirology, Neurology and Rheumatology, Department of Medicine, Kurume University School of Medicine, Fukuoka 830-0011, Japan; tateishi_takahisa@med.kurume-u.ac.jp

9 Suna and İnan Kıraç Foundation, Neurodegeneration Research Laboratory (KUTTAM-NDAL), Koc University, Istanbul 34450, Turkey

* Correspondence: mfujita@kumamoto-u.ac.jp (M.F.); nbasak@ku.edu.tr (A.N.B.); Tel.: +81-96-371-4622 (M.F.); +90-850-250-8250 (A.N.B.)

Abstract: Amyotrophic lateral sclerosis (ALS) is a rapidly debilitating fatal neurodegenerative disorder, causing muscle atrophy and weakness, which leads to paralysis and eventual death. ALS has a multifaceted nature affected by many pathological mechanisms, including oxidative stress (also via protein aggregation), mitochondrial dysfunction, glutamate-induced excitotoxicity, apoptosis, neuroinflammation, axonal degeneration, skeletal muscle deterioration and viruses. This complexity is a major obstacle in defeating ALS. At present, riluzole and edaravone are the only drugs that have passed clinical trials for the treatment of ALS, notwithstanding that they showed modest benefits in a limited population of ALS. A dextromethorphan hydrobromide and quinidine sulfate combination was also approved to treat pseudobulbar affect (PBA) in the course of ALS. Globally, there is a struggle to prevent or alleviate the symptoms of this neurodegenerative disease, including implementation of antisense oligonucleotides (ASOs), induced pluripotent stem cells (iPSCs), CRISPR-9/Cas technique, non-invasive brain stimulation (NIBS) or ALS-on-a-chip technology. Additionally, researchers have synthesized and screened new compounds to be effective in ALS beyond the drug repurposing strategy. Despite all these efforts, ALS treatment is largely limited to palliative care, and there is a strong need for new therapeutics to be developed. This review focuses on and discusses which therapeutic strategies have been followed so far and what can be done in the future for the treatment of ALS.

Keywords: amyotrophic lateral sclerosis (ALS); oxidative stress; protein aggregation; glutamate excitotoxicity; apoptosis; neuroinflammation; axonal degeneration; edaravone; riluzole; induced pluripotent stem cells (iPSCs) 


\section{Introduction}

Amyotrophic Lateral Sclerosis (ALS), also known as Lou Gehrig's or Charcot disease, is characterized by progressive deterioration of the upper and lower motor neurons in the brain and spinal cord, which leads to muscle weakness, paralysis and, finally, death due to respiratory failure within three to five years after the onset of the symptoms. ALS generally starts in limb or bulbar muscles, then spreads to other body parts and culminates in respiratory muscle dysfunction [1,2]. The primary symptoms of ALS due to motor neuronal degeneration are fasciculation, muscle cramps and stiffness, dysarthria, dysphagia, emotional lability (pseudobulbar affect (PBA)), which is characterized by uncontrolled laughter or crying, and dyspnea. Furthermore, sialorrhea usually occurs in ALS patients owing to dysphagia, and increased saliva production can result in aspiration pneumonia. In general, ALS patients also suffer from depression and anxiety [3,4].

An orphan or rare disease is defined as a condition that affects a small percentage of the population [5]. The incidence of ALS was reported to be between 0.6 and 3.8 per 100,000 persons-years [6,7]. Therefore, the United States Food and Drug Administration (FDA) consequently recognised ALS as an orphan disease [8]. Approximately $90 \%$ of ALS cases are sporadic (sALS), and the remaining 10\% cases are familial (fALS) [9]. In their clinical presentation, fALS and sALS are indistinguishable. Many environmental factors have been investigated in sALS. Advanced age (between 55 and 65 years) is an established risk factor, though fALS is generally related to a younger age of onset. Male gender, smoking, physical stress, exposure to heavy metals, persistent pollutants and environmental toxins such as $\beta$-methylamino-L-alanine, which is why people in Guam were susceptible to ALS with higher prevalence [10,11], are other risk factors that trigger sALS [12-14]. However, the genetic background, the etiology and the exact mechanisms of sALS are not yet known. The identification of genes responsible for fALS is shedding further light on the disease mechanisms underlying sALS [15]. In fALS, there are more than 25 utterly different genes participating in the familial disease, and this number is increasing. Point mutations in superoxide dismutase 1 (SOD1, 20\% of all fALS) and expanded GGGGCC repeats in C9orf72 are the most frequent ALS genes, whereas mutations in TAR deoxyribonucleic acid (DNA) binding protein 43 (TARDBP), fused in sarcoma/translocated in liposarcoma (FUS/TLS), TANK-binding kinase 1 (TBK1) or valosin-containing protein (VCP) account for less common genetic causes [16,17]. Interestingly, the existence of abnormal phosphorylated and ubiquitinated aggregates of TDP-43 is detected in approximately $97 \%$ of sALS patients, except for SOD1 and FUS cases [18].

The first animal model of ALS was a SOD1 ${ }^{\mathrm{G} 93 \mathrm{~A}}$ transgenic mouse model, generated based on a SOD1 mouse, harboring the glycine to alanine change at amino acid residue 93 (G93A) $[19,20]$. This transgenic model overexpressing mutant SOD1 is the most commonly used animal model in ALS for the screening of drug compounds at preclinical level. However, the majority of these compounds failed in human clinical trials, despite the promising outcomes obtained from preclinical studies [21,22]. Alternatively, mammalian cell lines transfected with the SOD1 mutants have been used in numerous studies (NSC-34 mouse neural hybrid cell line and SH-SY5Y human neuroblastoma cell line, e.g., [23-25]).

Oxidative stress, mitochondrial dysfunction, glutamate-induced excitotoxicity, apoptosis, neuroinflammation, axonal degeneration, skeletal muscle deterioration and viruses are other proven crucial pathologic mechanisms (Figure 1) associated with the formation of ALS, indicating that ALS is multifactorial syndrome rather than a single disease [26,27]. 


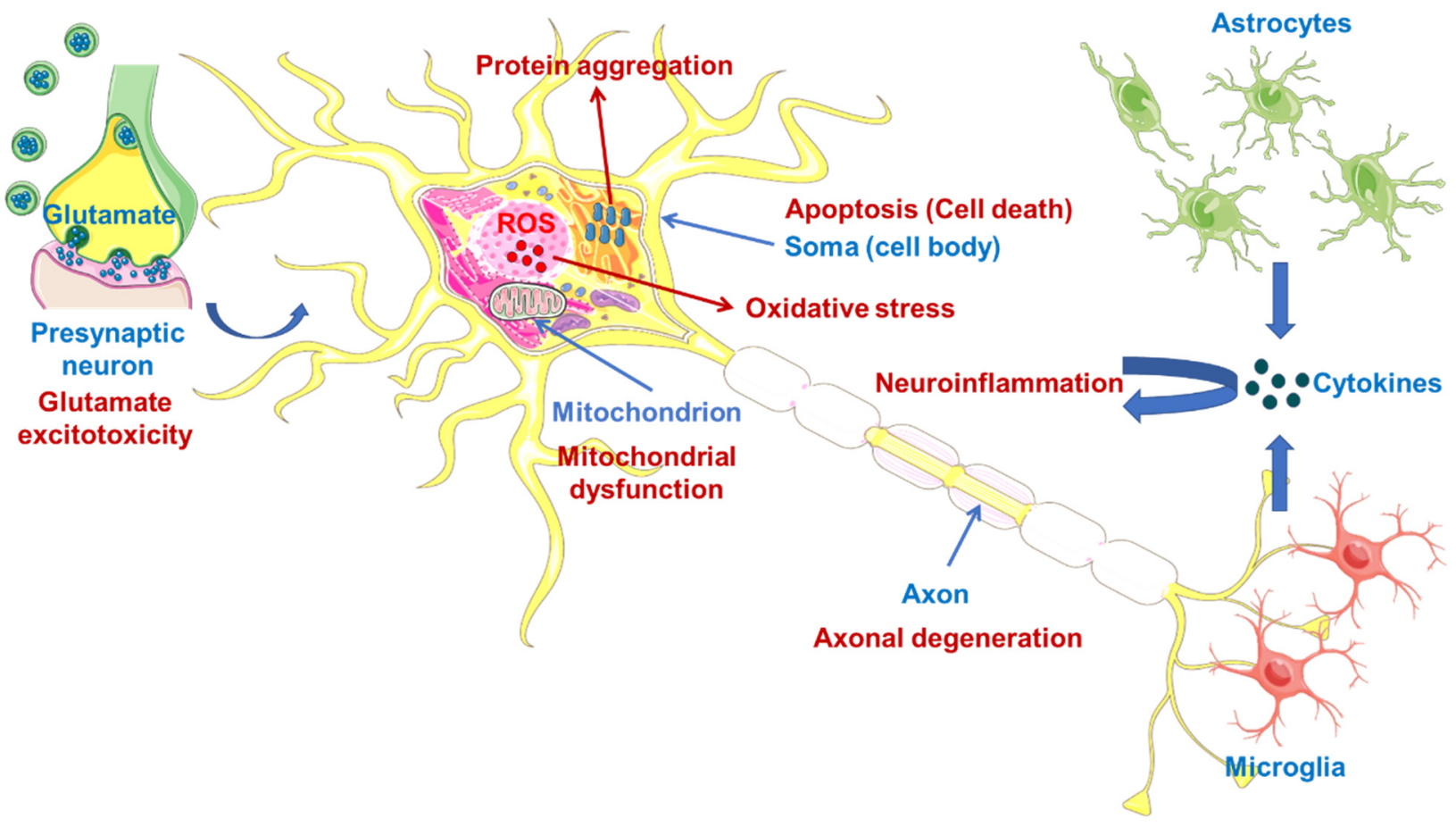

Figure 1. Some pathologic mechanisms in the central nervous system (CNS) related to the formation of ALS. Illustrations use elements from Servier Medical Art [28].

There is also a report that the gut microbiota, composed of bacteria, viruses, fungi and other microorganisms, and CNS disease-modifying bioactive metabolites derived from gastrointestinal tract can contribute to the pathogenesis of ALS [29]. In addition, a significant decrease in the expression of tight junction protein zona occludens protein 1 (ZO-1) and the adherens junction protein E-cadherin were observed in the intestine of SOD1 ${ }^{\mathrm{G} 93 \mathrm{~A}}$ ALS mice [30]. Other studies conducted with ALS patients also supported that gut microbiota could be a risk factor for ALS [31-33].

The blood-brain barrier (BBB), blood-spinal cord barrier (BSCB) and blood-cerebrospinal fluid barrier (BCSFB) play profound roles in the transfer of substances between the blood and brain/spinal cord. Any pathologic alteration in the BBB directly limits the passage of drugs, antibodies, gene carriers and stem cells from the capillaries to the CNS. Disintegration of the BBB and BSCB in areas of motor neuron injury in SOD1 ${ }^{\mathrm{G} 93 \mathrm{~A}}$ mice was observed at both early and late stages of ALS [34]. Abrahao et al. [35] deployed a first human trial relevant to the BBB opening in ALS patients using magnetic resonance-guided focused ultrasound (MRgFUS), and their results emphasized that this opening system could be coupled with the systemic administration of the most promising ALS therapeutics to directly target the degenerating motor cortex.

To date, edaravone (a free radical scavenger) and riluzole (a glutamate antagonist) are the only two drugs approved for use in the treatment of ALS, in spite of their limited beneficial effects on disease progression. The majority of other drugs have failed at phase III of clinical trials, which were performed with a larger cohort of ALS patients. Dextromethorphan hydrobromide and quinidine sulfate (Nuedexta ${ }^{\circledR}$ ) also received approval from the FDA to treat PBA. These outcomes indicate that the discovery of efficient disease-modifying therapies is an urgent need for the treatment of ALS [36,37].

The discovery of induced pluripotent stem cells (iPSCs), analogous to embryonic stem cells (ESCs) with their pluripotency and in vitro self-renewal capability, is one of the major breakthroughs holding great promise for the treatment of both fALS and sALS. iPSCs can differentiate into specific cell phenotypes, such as motor neurons and astrocytes, the main targets in ALS pathophysiology. Motor neurons generated from iPSCs derived from somatic cells (usually peripheral blood mononuclear cells (PBMCs) or skin fibroblasts) of ALS 
patients have provided a highly innovative technique for modelling the disease. Besides, compared to ESCs, iPSCs are generated from patients' own somatic cells, and thus there is a lack of ethical issues, decreased risk of immune rejection and limited immunosuppressive drug consumption. It is also beneficial that iPSCs retain the donor's genetic information, whereas animal models do not fully reflect the unique features of the human nervous system. On the other hand, the potential risk over time for iPSCs derived from patients is the probability of occurrence of a similar degeneration after transplantation. The progress in CRISPR-9/Cas technique, a genome editing tool, has facilitated the improvement in gene mutations in iPSCs, derived from patients, and the appropriate comparison between the model and individuals [38-42]. Wang et al. [43] generated iPSCs from fibroblasts of fALS patients harbouring mutations and gene-corrected ALS iPSCs using the CRISPR/Cas9 system. iPSC-based techniques provide great insight for drug discovery research on ALS. Based on iPSC-based technologies, bosutinib, ropinirole and retigabine have been identified as promising anti-ALS drugs, for which clinical trials are ongoing [15]. Furthermore, an ALS-on-a-chip technology using the 3D-model of the motor unit derived from iPSCs was developed to provide a platform for screening drug candidates and researching the pathogenesis of ALS [44].

Another approach for ALS treatment is using non-invasive brain stimulation (NIBS) techniques, which regulate brain activity by means of different energy forms, such as electrical current, magnetic pulses or focused ultrasound given throughout the scalp and skull. Some studies about the employment of NIBS to ALS were reviewed, and these techniques could prove beneficial for ALS after the standardization of stimulation procedures [45].

Based on aforementioned data, the clinical and pathogenic heterogeneity of ALS and the absence of well-characterized and controlled cellular or animal models that recapitulate the disease dreadfully restrained the success of the drug development process. Therefore, it is obvious that a single therapeutic approach is inadequate for people living with ALS. In this review, we focus on some drugs and related candidates which were expected to target diverse mechanisms responsible for ALS pathogenesis and examine preclinical and clinical trials. Additionally, some combinatorial approaches such as molecular hybridization, drug repurposing and iPSCs-based phenotypic screening are discussed in order to be useful for future applications in ALS drug discovery.

\section{Therapeutic Strategies for ALS Targets}

\subsection{Therapeutic Strategies against Oxidative Stress}

Oxidative stress is the consequence of the imbalance between the generation of reactive oxygen species (ROS), such as hydrogen peroxide $\left(\mathrm{H}_{2} \mathrm{O}_{2}\right)$, superoxide anions $\left(\mathrm{O}_{2}{ }^{-}\right)$and hydroxyl radicals $\left(\mathrm{OH}^{-}\right)$, and the ability of antioxidant defence system to clean or repair the existing damage to proteins and/or DNA. Normally, SOD1 converts the superoxide anion to $\mathrm{H}_{2} \mathrm{O}_{2}$, but as the SOD1 mutation shows lower affinity for $\mathrm{Zn}^{2+}$, it donates an electron to $\mathrm{O}_{2}$ to generate $\mathrm{O}_{2}{ }^{-}$at the $\mathrm{Cu}^{2+}$ catalytic site as a stronger oxidant and reacts with nitric oxide (NO) to form peroxynitrite $\left(\mathrm{ONOO}^{-}\right)$, which is very detrimental to CNS. ROS is considered to be a major mechanism in ALS causing motor neuron death, whereas some studies imply that ROS only exacerbates disease progression. When glutamate receptors are over-activated in the presence of higher glutamate levels in the synapse, elevated calcium influx into the cell also triggers the entry of calcium into the mitochondria, causing mitochondrial dysfunction, further ROS production and, ultimately, cell death. Glial and infiltrated immune cells also abundantly contribute to the production of ROS because glial synapses, which surround the devastated neurons, stimulate glutamate excitotoxicity and elevated calcium entry into the cell and mitochondria. As a result, each process in neuronal degeneration repeats itself, like a vicious circle [46-49].

Since lipids constitute polyunsaturated fatty acids, they are prone to oxidize to peroxyl radicals, resulting in cerebral ischemia. As phenol derivatives are well-known radical scavenging agents, Mitsubishi Tanabe Pharma Corporation developed potential phenol-like radical scavengers for the treatment of cerebral infarction. They designed compounds 
carrying a carbonyl group, which can easily convert to hydroxy group by keto-enol tautomerization to achieve radical scavenging activity, similar to that of the phenol provided by its hydroxy group (Figure 2a). They identified edaravone as an effective radical scavenger among a variety of compounds. Edaravone is capable of scavenging both lipidand water-soluble peroxyl radicals as well as $\mathrm{ONOO}^{-}$among many types of ROS. Researchers also reported that the in vitro lipid peroxidation inhibitory activity of edaravone was reduced with the substitution of polar or hydrophilic groups in the 2-pyrazoline-5-one ring, while this activity was increased with the lipophilic substitutions on the phenyl ring (Figure 2b) [50,51]. Edaravone interacts with both peroxyl (LOO') and hydroxyl ( $\mathrm{OH}$ ) radicals by means of its enolate form $(\mathbf{B})$, followed by the formation of a stable oxidation product (OPB: 2-oxo-3-(phenylhydrazono)-butanoic acid) through a radical intermediate (Figure 3) [52].

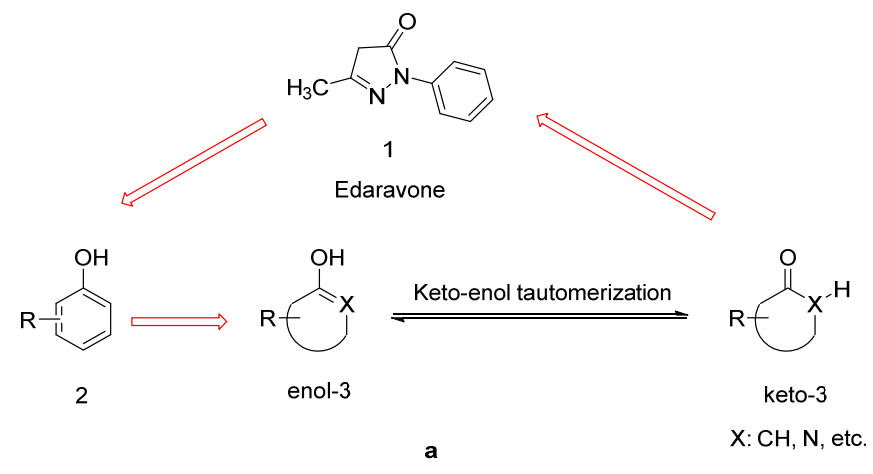

\section{Positions 3 and 4:}

Lipophilic moiety enhances the activity.

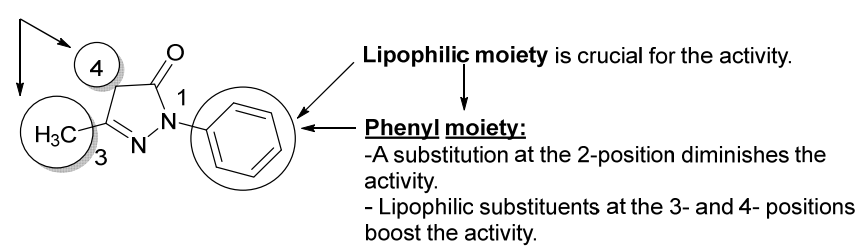

b

Figure 2. Design of a phenol-like compound (a), optimization of edaravone (b) $[50,51]$.<smiles>Cc1cc(-c2ccccc2)[nH]c(=O)c1</smiles><smiles>C=C</smiles><smiles>CC1=NN(c2ccccc2)C(=O)C1</smiles><smiles>C=C</smiles>

Edaravone<smiles>[B][14C](=O)C([O-])([O-])O</smiles>

OPB: 2-Oxo-3-(phenylhydrazono)-1-butanoic acid<smiles>Cc1cc(O)n(-c2ccccc2)n1</smiles>

Figure 3. Reaction mechanism of edaravone with free radicals [52]. 
Edaravone (MCI-186, 3-methyl-1-phenyl-2-pyrazoline-5-one, Radicut ${ }^{\circledR}$, Radicava ${ }^{\circledR}$ ), a neuroprotective antioxidant drug, was synthesized via the reaction of phenylhydrazine and acetoacetic ester by Knorr in 1883 [51]. This procedure was also applied in other studies, as follows: Phenylhydrazine and methyl acetoacetate were mixed in the presence of glacial acetic acid and stirred at reflux for $3 \mathrm{~h}$. The reaction mixture was evaporated to dryness and the residue was extracted with a mixture of water and ethyl acetate. The organic layer was separated, while the aqueous layer was further extracted with ethyl acetate. The combined organic layer was dried over anhydrous sodium sulphate and concentrated over reduced pressure to afford a pure product as a white solid (Figure 4) [53,54]. Edaravone (Figure 5) has been used to treat acute-phase cerebral infarction for almost 20 years in Japan. It received its approval for the treatment of ALS in Japan and South Korea in 2015; the FDA approved the drug in 2017 and Chinese-NMPA in 2019. In a phase II trial, $30 \mathrm{mg}$ or $60 \mathrm{mg}$ of edaravone was administered to 20 subjects with ALS. It was observed that the decline in the amyotrophic lateral sclerosis functional rating scale (ALSFRS-R) score was significantly reduced during the six-month treatment period [55]. In a randomised, doubleblind phase III study, a significantly smaller decline in the ALSFRS-R score compared with placebo group was also observed [56]. The exact mechanism of action of edaravone for ALS remains unclear; it has both neuroprotective effects against oxidative stress and antiinflammatory properties against activated microglial cells. So far, there has been no oral dosage formulation of edaravone clinically, thus it is used as an intravenous therapeutic for ALS management. However, oral dosage of edaravone for ALS patients is performed by Mitsubishi Tanabe Pharma Corporation under a phase $3 \mathrm{~b}$, multicentre, randomized, double-blind test, which has enrolled 380 ALS patients to examine and compare the efficacy of two dosing regimens of oral edaravone (Clinicaltrial.gov NCT04569084) [57-59].

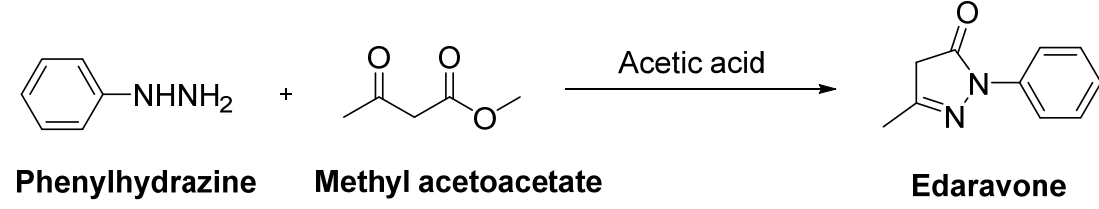

Figure 4. Synthetic route for edaravone.<smiles>CC1=NN(c2ccccc2)C(=O)C1</smiles>

Edaravone<smiles>CCCN[C@H]1CCc2nc(N)sc2C1</smiles>

Pramipexole<smiles>C#CCNC1CCc2ccccc21</smiles>

Rasagiline<smiles>CCCN[C@H]1CCc2nc(N)sc2C1</smiles>

Dexpramipexole<smiles>[R]OC(=O)O[Na]</smiles>

$$
\text { Rasagiline }
$$<smiles>C#CCN(C)[C@@H](C)Cc1ccccc1</smiles>

Selegiline<smiles>CC(C)C[C@H]1C(=O)N2CCC[C@H]2[C@@H]2O[C](NC(=O)[C@@H]3C=C4c5cccc6[nH]c(Br)c(c56)C[C@H]4N(C)C3)C(=O)N1[C@H]2C(C)C</smiles>

Bromocriptine<smiles>COc1ccc2[nH]cc(CCNC(C)=O)c2c1</smiles>

Melatonin

Figure 5. Therapeutics against oxidative stress. 
Dopamine receptor agonists used for the treatment of Parkinson's disease (PD) were also considered to be effective in ALS treatment. Pramipexole (Figure 5) has been shown to be a neuroprotective, reducing oxidative stress [60]. Dexpramipexole (Figure 5) is the optical enantiomer of pramipexole, with less affinity to dopamine receptors. Both compounds were screened in SOD1 ${ }^{\mathrm{G} 93 \mathrm{~A}}$ mice models, and dexpramipexole extended survival time and protected motor functions significantly more as compared to pramipexole [61]. In a randomised, double-blind, phase III trial in ALS, dexpramipexole was generally welltolerated, but no beneficial outcome was determined [62] in spite of a significant benefit in a phase II study with ALS patients [63]. Bromocriptine (Figure 5) is a free-radical scavenger and a dopamine receptor agonist used in the treatment of PD. It was reported that bromocriptine protected motor neurons from oxidative injury in SOD ${ }^{\mathrm{H} 46 \mathrm{R}}$ ALS mice models [64]. Furthermore, the results of a phase IIa, randomized, double-blind, placebocontrolled study conducted with Japanese ALS patients indicated that bromocriptine sustained motoneuronal activity, at least in part, by bromocriptine treatment, and this study stands out as promising for future phase IIlb or III clinical trials [65]. Another dopamine receptor agonist used in the treatment of $\mathrm{PD}$, ropinirole (Figure 5), was identified as a potential therapeutic candidate for ALS treatment from a large number of agents screened for the evaluation of multiple-phenotype rescue of sub-classified sALS models generated by using iPSCs [66]. A randomized, double-blind, placebo-controlled, single-center and openlabel phase I/IIa clinical trial (UMIN000034954) is ongoing for ropinirole hydrochloride to test safety, tolerance and efficacy in ALS [67].

A monoamine oxidase-B (MAO-B) inhibitor used to treat PD, rasagiline (Figure 5), has been proposed to protect motor neurons in ALS patients thanks to its antioxidative and anti-apoptotic properties [68]. Rasagiline displayed a dose-dependent therapeutic effect on both motor activity and survival in SOD ${ }^{\mathrm{G} 93 \mathrm{~A}}$ models of fALS, alone or in cotreatment with riluzole [69]. No difference in the primary outcome of survival was observed between groups in a randomised, double-blind, parallel-group, placebo-controlled, phase II trial in ALS conducted with rasagiline [70]. Besides, rasagiline was observed not to alter the disease progression compared with controls over a year of treatment in a randomized, doubleblind, placebo-controlled trial enrolling 80 ALS participants [71]. Selegiline (Figure 5), another MAO-B inhibitor with antioxidant properties, was also evaluated in a double-blind, placebo-controlled trial for treatment of ALS, but no significant effect was observed on the clinical progression of ALS [72].

Melatonin (Figure 5) is a potent antioxidant, anti-apoptotic and neuro-protectant agent [73]. In a combined study including cultured NSC-34 cells, SOD1 ${ }^{\text {G93A }}$ mouse models and sALS clinical models enrolling 31 ALS patients demonstrated that in melatonin-reduced glutamate-induced cell death in NSC-34 cells, high-dose oral melatonin slowed disease progression and prolonged survival of SOD1 ${ }^{\mathrm{G} 93 \mathrm{~A}}$ mice. Furthermore, chronic high-dose (300 mg/day) rectal melatonin was well-tolerated in ALS patients [74]. In another recent study, a decline in annualized hazard death and a slower rate of decline in ALSFRS-R score was detected in melatonin users when compared with the non-melatonin users [75].

\subsection{Therapeutic Strategies against Oxidative Stress via Protein Aggregation}

SOD1 is a $\mathrm{Cu} / \mathrm{Zn}$-dependent antioxidant enzyme that catalyses the conversion of superoxide radicals to oxygen and hydrogen peroxide, thus regulating the superoxide levels that arise from mitochondrial inter-membrane space, cytosol and peroxisome. The discovery of the connection between mutations in the SOD1 gene with certain forms of fALS made a tremendous impact in understanding the pathology of ALS. SOD1 mutations have been reported to contribute to ALS through not only protein misfolding and aggregation, but also proteasome impairment, oxidative stress, oligodendrocyte degeneration and mitochondrial dysfunction [76,77].

In order to decrease SOD1 expression and increase SOD1 consumption, antisense oligonucleotides (ASOs) and heat shock protein (HSP) inducers were pursued, respectively. ASOs are short, synthetic nucleic acids which are suitable for chemical modification for high 
stability in biological fluids and potency in binding their mRNA target. ASOs targeting SOD1 mRNA reduced both SOD1 protein and mRNA levels throughout the brain and spinal cord in the SOD1 ${ }^{\text {G93A }}$ mice model [78]. Tofersen (BIIB067, ISIS 333611, IONIS-SOD1Rx) is a type of antisense therapy. A randomised, placebo-controlled, first-in-man phase I clinical trial with SOD1-positive ALS patients indicated that ISIS 333611 was well-tolerated when administered as an intrathecal infusion [79]. A second phase I/II trial with BIIB067 was designed to decrease SOD1 mRNA in ALS patients carrying a SOD1 gene mutation. Results showed that a statistically significant reduction in cerebrospinal fluid (CSF)-SOD1 suggested substantial reduction in CNS tissue SOD1. Besides reduced CSF phosphorylated heavy neurofilament, a decline in ALSFRS-R scores were also detected in ALS patients [80]. A phase III trial of BIIB067 is currently ongoing (Clinicaltrial.gov NCT02623699).

HSPs such as Hsp27, Hsp40 and Hsp70 were associated with mutant SOD1 aggregates in SOD1 rodent models of ALS. Arimoclomol (Figure 6), a hydroxylamine-based HSP amplifier, was determined to extend survival and delay disease onset with improvement in neuromuscular activity in the SOD $1^{\mathrm{G} 93 \mathrm{~A}}$ mouse model of ALS [81,82]. A double-blind, randomized, placebo-controlled phase II trial enrolling patients with rapidly progressive SOD1-mutant ALS suggested a possible therapeutic benefit of arimoclomol [83]. A randomized, double blind, placebo-controlled phase III trial has been completed, but results are not yet posted (Clinicaltrial.gov NCT03491462) [84]. Furthermore, HSPB8, a specific chaperone, was found to be effective in stimulating the clearance of the misfolded proteins related to motor neuron diseases, such as mutant SOD1 and a TDP-43 fragment in ALS. Colchicine (Figure 6), an anti-inflammatory drug generally used in gout treatment, enhances the expression of HSPB8. Colchicine was shown to reduce the aggregation of TDP-43 misfolded species responsible for motor neuron death in sALS [85]. A randomised, double-blind, placebo-controlled, multicentre phase II clinical trial is ongoing for colchicine (Clinicaltrial.gov NCT03693781) [86].<smiles>[O-][n+]1cccc(/C(Cl)=N/OCC(O)CN2CCCCC2)c1</smiles>

Arimoclomol<smiles>COc1ccc2c(c1)C(NC(C)=O)CCc1cc(OC)c(OC)c(OC)c1-2</smiles>

Colchicine<smiles>CNC1=NN[Si](N2N=C(C)C(C)=NN=C2NC)S1</smiles>

Cu"(atsm)<smiles>CCc1nc(N)nc(N)c1-c1ccc(Cl)cc1</smiles>

Pyrimethamine<smiles>O=c1c2ccccc2[se]n1-c1ccccc1</smiles>

Ebselen

Figure 6. Therapeutics against oxidative stress via protein aggregation.

$\mathrm{Cu}^{\mathrm{II}}$ (atsm) (Figure 6) is a copper carrying compound which is capable of crossing the $\mathrm{BBB}$, and it has been developed as a potential new anti-ALS agent. $\mathrm{Cu}^{\mathrm{II}}$ (atsm) treatment aims to maintain bioavailable copper to mutant SOD1 to keep it in a stable physiological holo form, as mutant SOD1 aggregates are observed at abnormal copper-deficient state [87]. The preclinical potential of $\mathrm{Cu}^{\mathrm{II}}(\mathrm{atsm})$ in ALS was investigated in the SOD1 ${ }^{\mathrm{G} 37 \mathrm{R}}$ mouse model. According to the results, $\mathrm{Cu}^{\mathrm{II}}$ (atsm) enhanced locomotor performance and prolonged mouse survival in a dose-dependent manner [88]. Phase II/III testing is in progress after successful completion of the phase I trial in ALS patients. In this assay involving 
post-mortem spinal cord tissue from sALS, it is considered that $\mathrm{Cu}^{\mathrm{II}}($ atsm) can be beneficial to sALS, enabling copper to transfer from the complex into mutant SOD1 [89].

The antimalarial drug pyrimethamine (Figure 6) was identified by high-throughput screening (HTS) to lower SOD1 protein levels in human cells in a dose-dependent manner. Therefore, a phase I study enrolling 16 ALS patients harbouring SOD1 mutations was performed. These findings supported the connection of a reduction in SOD1 in ALS patients with pyrimethamine use. However, the significance is not yet fully understood [90]. Another study also demonstrated that pyrimethamine caused a significant reduction in total CSF mutant SOD1 levels in ALS patients in addition to its safety and well-tolerated profile, though the molecular target by which pyrimethamine decreases the SOD1 amount is not yet known [91].

Capper et al. [92] reported that the cysteine-reactive molecule ebselen (Figure 6) was able to engage with Cys111, which is prone to oxidative modifications in SOD1ALS. Ebselen forms a covalent bond with SOD1-Cys111 and repairs the monomer-dimer equilibrium of SOD1 $1^{\mathrm{A} 4 \mathrm{~V}}$ to wildtype, acting as a potent bifunctional pharmacological chaperone for SOD1 endowed with combinatory properties of human copper chaperone for SOD1 (hCCS) and edaravone.

\subsection{Therapeutic Strategies against Mitochondrial Dysfunction}

Mitochondria are essential cell organelles that elicit adenosine triphosphate (ATP) through oxidative phosphorylation, regulate calcium homeostasis and produce ROS as a by-product of the electron transport chain. Dysfunction of this electron transport chain can cause increased levels of mitochondrial oxygen consumption and ROS production along with decreased ATP synthesis and DNA repair. Mitochondrial dysfunction also triggers oxidative stress and glutamate excitotoxicity in ALS. Abnormal morphology and ALS-linked mutant proteins were observed in mitochondria of sALS post-mortem tissue $[47,48,93]$.

Olesoxime (TRO19622) (Figure 7) is a mitochondrial pore modulator with a cholesterollike structure. Bordet et al. [94] determined that olesoxime in vitro promoted motor neuron survival among a collection of a great number of low molecular-weight compounds which were capable of preventing motor neuron cell death. This compound was also found to improve motor performance, delay the onset of the clinical disease and extend survival in $\mathrm{SOD1}{ }^{\mathrm{G} 93 \mathrm{~A}}$ transgenic mice. They also suggested that olesoxime displayed neuroprotective activity, binding to the mitochondrial permeability transition pore (mPTP). However, a phase II-III trial of olesoxime in subjects with ALS revealed that olesoxime did not show a significant beneficial effect in ALS patients treated with riluzole [95].<smiles>CC(C)CCCC(C)C1CCC2C3CCC4=CC(=NO)CCC4(C)C3CCC12CCCO</smiles><smiles>CN(CC(=O)O)C(=N)N</smiles><smiles>COC1C(=O)C(C)=C(C=CC(C)C)C(OC)C1=O</smiles>

\section{Coenzyme Q10}

Figure 7. Therapeutics against mitochondrial dysfunction.

Creatine (Figure 7), phosphorylated by creatine kinase, is involved in ATP production. Therefore, creatine stabilizes the mitochondrial creatine kinase and inhibits opening of the mPTP. It was detected that creatine improved motor performance and extended survival 
in SOD1G93A mice [96]. However, a double-blind, placebo-controlled, sequential clinical trial established that creatine monohydrate showed no beneficial effect on survival or disease progression in ALS patients [97]. Creatine also displayed no benefit in any outcome measure in a randomized double-blind, placebo-controlled trial on 104 ALS patients [98] or in another multicentre, double-blinded study with 107 ALS patients [99]. Coenzyme Q10 (CoQ10) (Figure 7), an electron acceptor in the mitochondrial respiratory chain, was reported to increase lifespan in SOD1 ${ }^{\mathrm{G} 93 \mathrm{~A}}$ mice [100]. In a two-stage, bias-adjusted, randomized, placebo-controlled, double-blind, phase II design performed for CoQ10 in 185 ALS patients, a decline in ALSFRS-R score and insufficient data were observed for further phase III testing [101].

\subsection{Therapeutic Strategies against Glutamate-Induced Excitotoxicity}

It has long been known that abnormal levels of glutamate, which is the main excitatory neurotransmitter in the brain, can cause neurodegenerative effects. The $\alpha$-amino3-hidroxy-5-methyl-4-isoxazole-propionic acid (AMPA) and the N-methyl-D-aspartate (NMDA) receptors, two important ionotropic glutamate receptors, are mediators of glutamate excitotoxicity owing to poor buffering calcium influx capacity of their subunits, such as the GluA2 subunit of the AMPA receptor. Massive entry of calcium into the cell stimulates phospholipases, proteases and endonucleases, causing devastation of energy metabolism and apoptotic or necrotic cell death. Besides, reduced expression of astrocytic excitatory amino-acid transporters (EAATs) is crucial for clearance of glutamate from the synaptic cleft into astrocytes, and defects in glutamate transport have been linked with ALS pathogenesis [102-104].

Riluzole (6-(trifluoromethoxy)-2-aminobenzothiazole) was discovered due to its remarkable anticonvulsant properties during the 1980s. The reaction of 4-(trifluoromethoxy) aniline with tetrabutylammonium thiocyanate afforded riluzole, in the presence of dichloromethane, with a yield of $61 \%$. An alternative synthetic route for riluzole is the reaction of 4-(trifluoromethoxy)aniline with ammonium thiocyanate in the presence of acetonitrile (71\%) (Figure 8) [105]. Riluzole (Figure 9) has been reported to exhibit neuroprotective effects in several animal models of PD, Huntington's disease and cerebral ischemia [106]. Moreover, two large randomized placebo-controlled clinical trials were carried out to investigate the potency of riluzole in ALS treatment [107]. A double-blind, placebo-controlled phase II trial enrolling 155 ALS outpatients showed that riluzole slowed the disease progression and improve survival in patients [108]. In order to confirm and extend the therapeutic effect of riluzole, a double-blind, placebo-controlled, multicentre, international, dose-ranging study was performed on a large number of ALS outpatients. Results showed that it was well-tolerated and diminished the risk of death or tracheostomy in ALS patients [109]. Riluzole was approved by the FDA in 1995 and subsequently launched into the market under the trade name, Rilutek ${ }^{\circledR}$. Riluzole, the first FDA-approved drug for the treatment of ALS, showed its mechanism via enhancement of extracellular glutamate uptake and inhibition of glutamate release from presynaptic terminals. Furthermore, riluzole also stabilizes the inactivated state of voltage-dependent sodium channels and NMDA receptor-mediated responses [110]. On the other hand, riluzole, dexpramipexole and pramipexole are 1,3-benzothiazole-based derivatives, though they display their antiALS activities in a different manner, implying the importance of the compounds carrying the same structural moiety endowed with different functions [111].

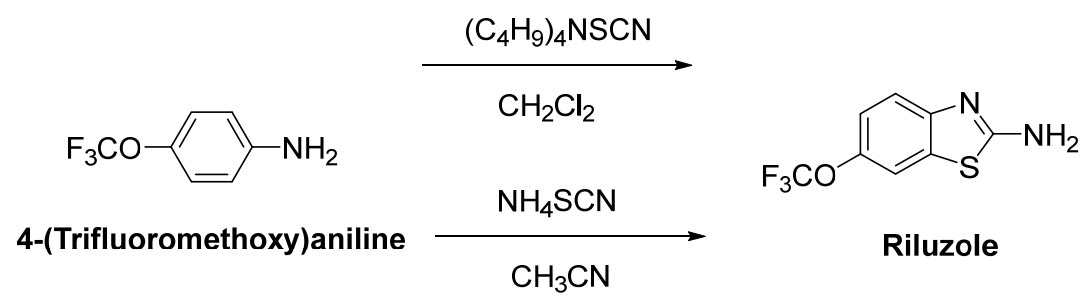

Figure 8. One-pot synthetic routes for riluzole. 


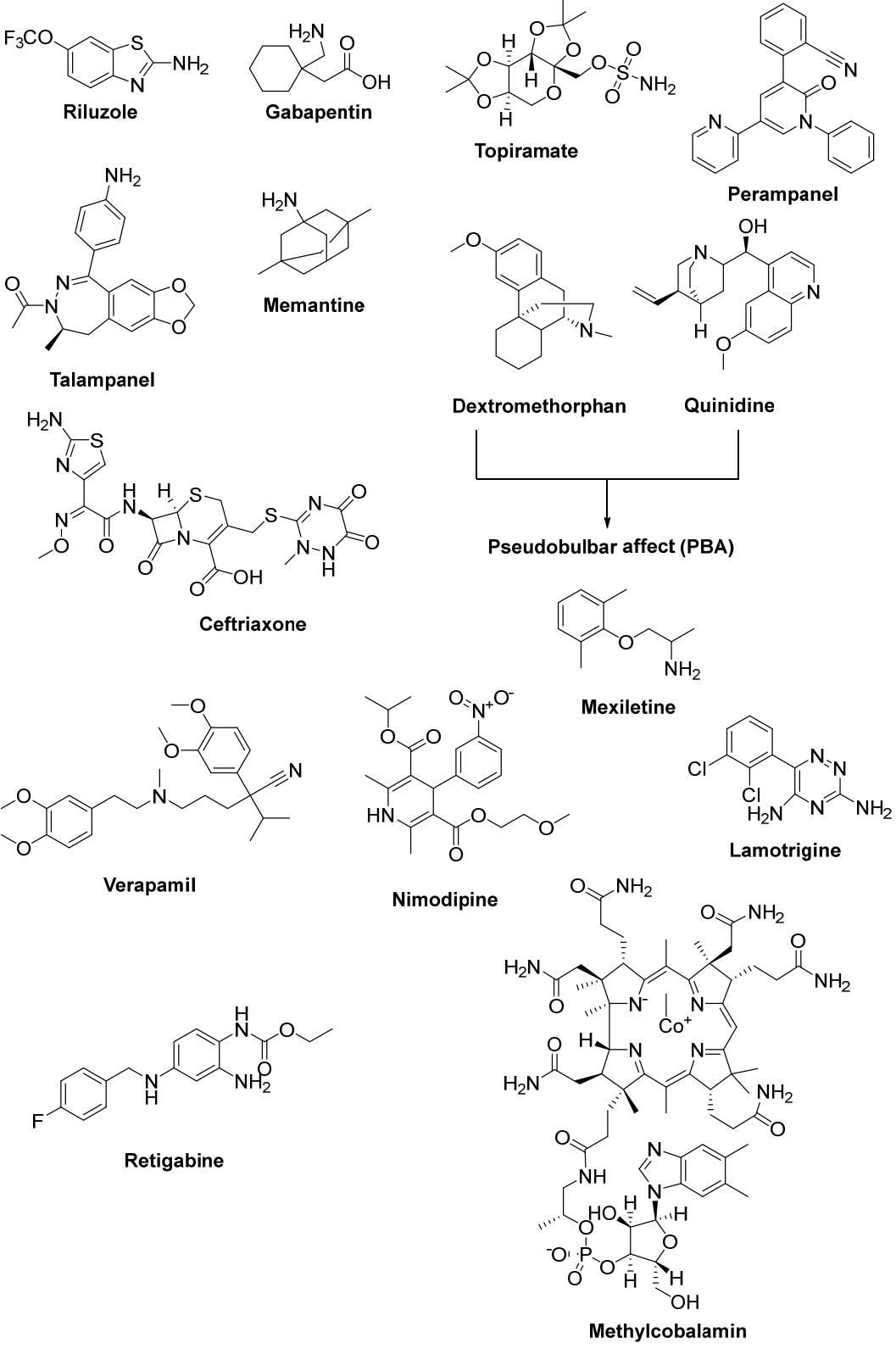

Figure 9. Therapeutics against glutamate-induced excitotoxicity.

Gabapentin (Figure 9), a lipophilic analogue of $\gamma$-aminobutyric acid (GABA), is an antiepileptic drug and a modulator of the glutamatergic system. Due to its diminished effects on glutamate excitotoxicity, it was considered to be effective in ALS patients. After successful results of preclinical and clinical studies of gabapentin, a phase III randomized clinical trial was also undertaken. However, there were no data obtained showing any beneficial effect on symptoms and disease progression in ALS patients [112,113].

As an AMPA receptor antagonist and an antiepileptic drug, topiramate (Figure 9), was determined to maintain motor neurons from glutamate excitotoxicity in a dose-dependent manner in an in vitro model. However, a controlled clinical trial exhibited that the maximum tolerated dosage of topiramate was related to severe adverse effects and absence of efficacy [114,115]. Another AMPA receptor antagonist, perampanel (Figure 9), shows its effect via the inhibition of the excitation of postsynaptic membranes. It was deduced that it slowed the development of the ALS phenotype and boosted the number of anterior horn cells in transgenic mice [116]. However, an open label pilot study, which was conducted to search for the tolerability and safety of perampanel in ALS patients, was terminated owing to the high number of adverse events [117]. Perampanel was also determined to 
cause a decline in ALSFRS-R score, along with several adverse events, in a randomized, double-blind, placebo-controlled, multicentre, phase II clinical study [118].

On the other hand, talampanel (Figure 9) is a non-competitive AMPA receptor blocker and belongs to a structural class of substituted benzodiazepines. It was observed from a study in a mutant SOD1 mouse model of ALS that talampanel could be beneficial in the earlier stages of the disease [119]. Moreover, in talampanel-treated subjects, declines in muscle strength and in the ALSFRS-R score were found to be $15 \%$ and $30 \%$ less, respectively, in a double-blind, placebo-controlled, multicenter, randomized phase II trial. This study also indicated that talampanel was sufficiently well-tolerated in subjects with ALS for further a phase III trial [120].

Memantine (Figure 9) is a non-competitive NMDA receptor antagonist marketed for advanced stages of Alzheimer's disease. It was revealed that memantine delayed the disease progression and increased the life span of SOD1 ${ }^{\mathrm{G} 93 \mathrm{~A}}$ mice [121]. In a phase II/III, 12-month, double-blinded, single-centre, randomized clinical trial, which was carried out to determine the efficacy and safety of memantine in ALS, the tolerance and safety profile of memantine in ALS patients was confirmed, however, no evidence of efficacy was obtained [122]. A new multicentred double blind and placebo-controlled study is ongoing (Clinicaltrial.gov NCT02118727) to determine whether combination therapy of memantine with riluzole can improve the progression of the disease, along with cognitive deficits. Dextromethorphan (Figure 9) is an NMDA-glutamate receptor antagonist that also displays cough suppressant properties. A randomized, double-blind, placebo-controlled study enrolling 45 ALS patients substantiated that a relatively low dose of dextromethorphan revealed no recovery in one year survival in ALS [123]. Moreover, quinidine (Figure 9) can enable high plasma dextromethorphan concentrations, preventing its metabolism. Therefore, the combination of dextromethorphan hydrobromide and quinidine sulfate (Figure 9) was found to regulate symptoms of PBA acting on the Sigma-1 receptor and is approved by the FDA for the treatment of PBA in patients with ALS [124,125].

Intriguingly, ceftriaxone (Figure 9), a member of third generation $\beta$-lactam antibiotics, was reported to intercept glutamate-induced excitotoxicity by elevating the expression and functional activity of EAAT2. In a study conducted with SOD1 ${ }^{\text {G93A }}$ mice, ceftriaxone postponed the loss of neurons and extended survival time [126]. Promising results were achieved at stages I and II of a three-stage randomised, double-blind, placebo-controlled study of ceftriaxone in ALS; however, ceftriaxone displayed no clinical efficacy at stage III [127]. In a structural manner, ceftriaxone shares a similar lactam ring and an exocyclic amide group with bromocriptine, a free-radical scavenger, despite their distinct mechanisms (reducing glutamate excitotoxicity and oxidative stress, respectively), suggesting that the lactam ring or exocyclic amide group could be important regions for anti-ALS function [128].

Calcium channel blockers were also considered to be potent in ALS treatment by reducing the downstream effects of glutamate excitotoxicity by means of remittance of calcium entry into damaged neurons. A phase II clinical study revealed that verapamil (Figure 9) was ineffective in retarding the progression of ALS [129]. Another randomized, placebo-controlled, double-blind crossover study enrolling 87 ALS patients revealed that nimodipine (Figure 9) was also found ineffective in slowing the progression of ALS [130]. On the other hand, mexiletine (Figure 9) has potential for lowering hyperexcitability as a sodium channel blocker. Therefore, it underwent clinical trials for ALS treatment. A single blind, randomized, controlled phase II trial of mexiletine concluded that a daily $300 \mathrm{mg}$ dose of mexiletine had no effects on axonal sodium current and ALSFRS-R score [131]. A different randomized trial of mexiletine in ALS indicated that mexiletine also had no effect on rate of progression when administered daily to ALS patients as $300 \mathrm{mg}$ and $900 \mathrm{mg}$ doses [132]. Another randomized, double-blind, crossover trial indicated that $150 \mathrm{mg}$ mexiletine twice daily was well-tolerated and effective for controlling the symptom of muscle cramps in ALS [133]. A phenyltriazine-based antiepileptic agent, lamotrigine (Figure 9), inhibits both sodium and calcium channels and hampers glutamate presynaptic 
release. According to a double-blind, placebo-controlled, crossover study, no clinical effect of lamotrigine on ALS progression was detected [134-136]. Retigabine (ezogabine) (Figure 9) is an anticonvulsant drug which activates a voltage-gated potassium-channel. Retigabine was found to reduce hyperexcitability and extend motor neuron survival in iPSC-derived motor neurons from ALS patients harbouring SOD1 mutations [137]. A phase II randomized clinical trial of retigabine enrolling 65 ALS patients showed that retigabine diminished cortical and spinal motor neuron excitability in a dose-dependent manner [138].

The vitamin $B_{12}$ analog, methylcobalamin (Figure 9), was reported to possess neuroprotective properties towards glutamate-induced cytotoxicity [139]. It was anticipated, in a study conducted in the wobbler mouse model of ALS, that methylcobalamin would show improvements in motor symptoms at very high dose levels [140]. Although a long-term phase II/III randomised controlled study enrolling 373 ALS patients revealed less decline in the ALSFRS-R score along with low treatment-related adverse events, there was no significant efficacy in the whole cohort. This treatment could extend survival and decrease symptomatic progression without major side effects if started early [141].

\subsection{Therapeutic Strategies for Reducing Apoptosis and/or Boosting Autophagy}

Apoptosis is another potential mechanism of motor neuron death in ALS. It is termed as suicidal death of cells with a certain morphology, whereas autophagy is lysozymemediated sequestration of cytoplasmic material in vacuoles for bulk degradation. Autophagy is responsible for removing protein aggregates, damaged or redundant organelles through mitochondria or the endoplasmic reticulum along with toxic metabolites, cancer cells and intact microorganisms. Due to their lack of proliferation capacity and their high energy consumption, autophagy is essential for neurons to remove protein aggregates and damaged cellular inclusions. The Bcl-2 family proteins, as suppressors (Bcl-2, Bcl-XL) or promoters (Bax, Bad, Bak and Bcl-xS), regulate apoptosis, and it has recently become clear that they also control autophagy [142,143].

The Abelson non-receptor tyrosine kinase (c-Abl, Abl1) is normally activated in the $\mathrm{Bcr}-\mathrm{Abl}$ hybrid protein of chronic myelogenous leukemia (CML). In addition to its oncogenic potential, overexpression of active c-Abl induces apoptosis and cell cycle arrest in response to a wide range of stimuli, such as inflammation, DNA damage, amyloid- $\beta$ and oxidative stress, resulting in neurodegeneration and neuroinflammation [144,145]. It was also rationally hypothesized that activation of the Src/c-Abl signalling pathway synergistically leads to apoptosis in non-dividing cells (motor neurons) and the secretion of inflammatory factors in dividing cells (astrocytes and microglia) (Figure 10) [146]. There is growing evidence that the c-Abl pathway is a therapeutic target in ALS, based on the studies in cell culture revealing that inhibition of c-Abl protects cortical neurons from DNA damage-induced apoptosis [147]. Moreover, a robust rise in the phosphorylation of c-Abl in the brain and spinal cord of symptomatic SOD1 ${ }^{\mathrm{G} 93 \mathrm{~A}}$ mice and in the spinal cord and motor cortex of symptomatic SOD1 ${ }^{\mathrm{G} 86 \mathrm{R}}$ mice was observed [148]. It was also documented that c-Abl expression was increased three-fold in post-mortem spinal cord tissues from sALS patients compared with non-ALS patients [149].

Katsumata et al. [149] designated that mutations of SOD1 activated the upregulation of c-Abl and alleviated cell viability. Additionally, dasatinib (Figure 11), a BBB-permeable $\mathrm{c}-\mathrm{Abl}$ inhibitor, prevented cytotoxicity of mutant SOD1 proteins. Activation of c-Abl and caspase- 3 was observed in SOD1 ${ }^{\mathrm{G} 93 \mathrm{~A}}$ mice. Dasatinib extended the survival of SOD1 ${ }^{\mathrm{G} 93 \mathrm{~A}}$ mice and diminished c-Abl phosphorylation. Imatinib (Figure 11), the c-Abl inhibitor used to treat $\mathrm{CML}$, was reported to inhibit $\mathrm{c}-\mathrm{Abl}$ phosphorylation in primary neuronal cultures at micromolar levels in response to various stimuli, such as oxidative stress. Imatinib was also determined to prevent astrocyte conditioned media (ACM)-hSOD1 ${ }^{\mathrm{G} 93 \mathrm{~A}}$-mediated motoneuron death [148]. Imamura et al. [150] determined that Src/c-Abl could be an efficient target for ALS treatment, based on HTS conducted for 1416 compounds, using ALS survival of motor neurons generated from an ALS patient harbouring SOD1 mutations. Bosutinib (Figure 11), a Src/c-Abl inhibitor used for treatment of CML, increased autophagy 
and reduced the levels of misfolded SOD1. Similar results were obtained with other mutations including TDP-43 and C9ORF72. Furthermore, bosutinib treatment modestly increased the life span of a mutant SOD1 ALS mice model. Bosutinib is currently in an open-label, multicentre phase I trial for ALS (UMIN000036295) to evaluate its safety and tolerability for the treatment of ALS patients and to explore its efficacy on ALS [151].

ALS

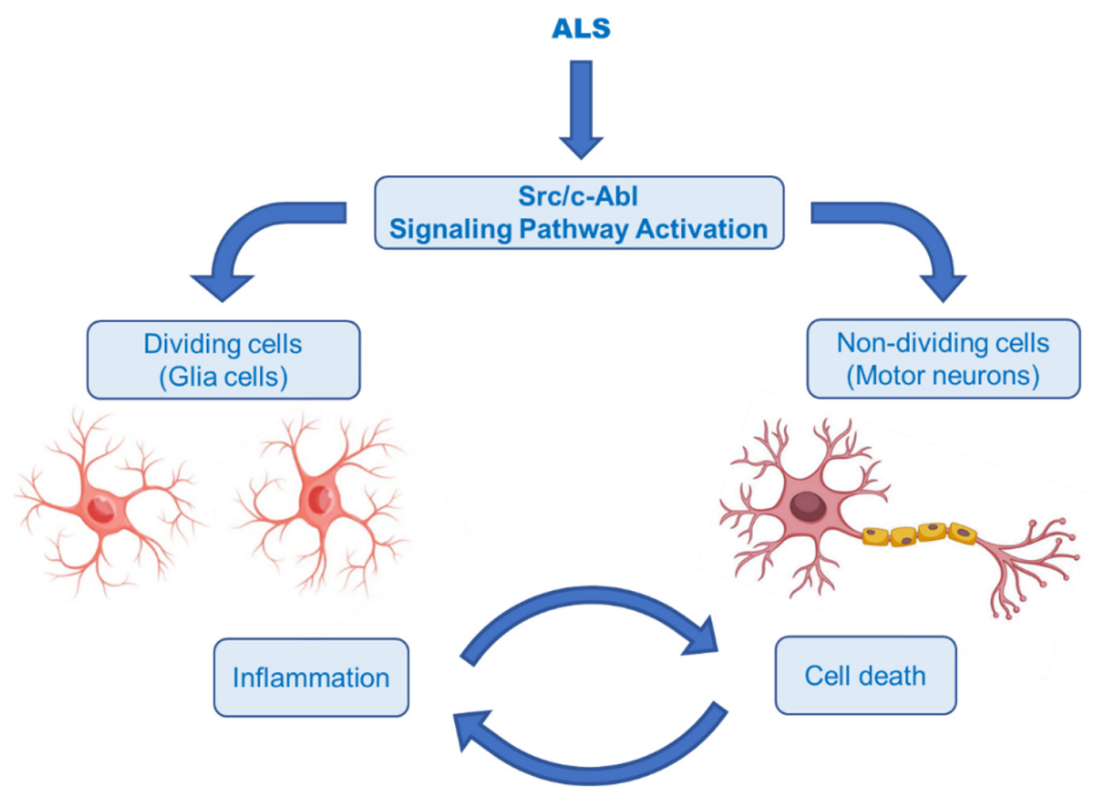

Figure 10. Hypothesis of the ALS pathomechanism in dividing and non-dividing cells [146]. Illustrations use elements from Servier Medical Art [28].<smiles>Cc1nc(Nc2ncc(C(=O)Nc3c(C)cccc3Cl)s2)cc(N2CCN(CCO)CC2)n1</smiles>

Dasatinib<smiles>COc1cc(Nc2c(C#N)cnc3cc(OCCCN4CCN(C)CC4)c(OC)cc23)c(Cl)cc1Cl</smiles>

Bosutinib

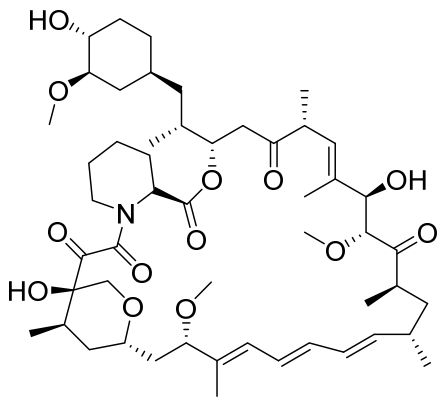

Rapamycin<smiles>Cc1ccc(NC(=O)c2ccc(CN3CCN(C)CC3)cc2)cc1Nc1nccc(-c2cccnc2)n1</smiles>

Imatinib<smiles>CC(CCC(=O)NCCS(=O)(=O)O)C1CCC2C3C(O)CC4CC(O)CCC4C3(C)CCCC12C</smiles>

Tauroursodeoxycholic acid (TUDCA)

Figure 11. Therapeutics for reducing apoptosis and/or boosting autophagy. 
A hydrophilic bile acid used for treatment of chronic cholestatic liver disorders, tauroursodeoxycholic acid (TUDCA) (Figure 11), was identified to inhibit apoptosis in ventral mesencephalic tissue cultures and within the transplants [152]. A double-blind placebocontrolled trial enrolling 34 ALS patients determined that TUDCA was well-tolerated and, at study end, the baseline-adjusted ALSFRS-R score was found to be higher in TUDCAtreated cohorts than in placebo cohorts [153]. A phase III clinical trial for TUDCA with more participants is ongoing (Clinicaltrial.gov NCT03800524).

Rapamycin (Sirolimus ${ }^{\circledR}$ ) (Figure 11) is used clinically to hamper solid organ transplant rejection. It is also identified as a mammalian target of rapamycin (mTOR) inhibitor and consequent autophagy activator [154]. In regard to these properties, rapamycin discernibly counteracted accumulation of misfolded proteins and exhibited beneficial effects in studies using different cell lines and ALS animal models. A randomized, double-blind, placebo controlled, multicenter phase II clinical trial continues for rapamycin with ALS patients (Clinicaltrial.gov NCT03359538) [155]. Lithium is a glycogen synthase kinase-3 (GSK-3) inhibitor and is currently used to treat bipolar disorder. Moreover, lithium is an inositol monophosphatase 1 (IMPA 1) inhibitor, and thus a mTOR-independent autophagy inducer [154]. It was reported that lithium administration to SOD1 ${ }^{\mathrm{G} 93 \mathrm{~A}}$ mice promoted life span and activated autophagy [156]. A randomised, double-blind, placebo-controlled trial in ALS patients indicated no beneficial effect of lithium on survival and safety concerns [157]. Another double-blind, placebo-controlled trial with a combination of lithium with riluzole did not alleviate the progression of ALS more than riluzole alone [158]. Valproic acid (Figure 11), an antiepileptic drug, is a histone deacetylase (HDAC) and GSK-3 inhibitor. It also has antiapoptotic properties through upregulation of Bcl-2 protein. A study including the treatment SOD1 ${ }^{\mathrm{G} 93 \mathrm{~A}}$ mice with valproic acid accentuated a significant prolongation of the disease's duration [159]. Conversely, a randomized sequential study of valproic acid in ALS patients provided no advantage to survival or disease progression [160]. As the cotreatment, lithium with valproic acid was found to halt glutamate excitotoxicity; this synergistic effect was considered to be effective in ALS [161]. A study performed with SOD1 ${ }^{\mathrm{G} 93 \mathrm{~A}}$ mice demonstrated that this combined treatment resulted in longer lifespan compared to monotreatment with lithium or valproic acid [162]. In a clinical experiment, cotreatment of valproic acid and lithium significantly boosted survival and neuroprotection in sALS patients beyond late adverse events [163].

\subsection{Therapeutic Strategies against Neuroinflammation}

Neuroinflammation is another important pathological mechanism in ALS progression. It is characterized by the activation of microglia and astrocytes, infiltration of immune cells (lymphocytes, macrophages, mast cells, neutrophils, etc.) and higher levels of inflammatory mediators. Microglia are generally divided into inflammatory (M1) and activated (M2) phenotypes. The M1 is linked with the release of proinflammatory cytokines (tumour necrosis factor (TNF)- $\alpha$, interleukin-6 (IL-6), IL-23, IL-1 $\beta$, IL-12, NO), cytotoxic substances (ROS), prostaglandin E2, chemokines, dysregulated glutamate levels, whereas M2 expresses anti-inflammatory molecules such as IL-10 and transforming growth factor (TGF)- $\beta$. There is mounting evidence regarding the connection between neuroinflammation with neuronal loss in sALS and fALS. Initially, glia and T cells, especially M2 macrophages/microglia, and T helper (Th) 2 cells and regulatory $\mathrm{T}$ (Treg) cells have protective roles in maintaining motor neuron viability. At a later stage, cytotoxic M1 macrophages/microglia and proinflammatory Th1 and Th17 T cells become more active [164-168].

Tocilizumab is an antibody that inhibits signalling of IL-6, a well-known promoter of the development of Th17 cells. It is currently used in patients with rheumatoid arthritis. A pilot study documented that in vitro tocilizumab mitigated several factors, including IL-6, that drive inflammation in sALS patients [169]. Another study including in vivo baseline inflammatory gene transcription in PBMCs of sALS patients indicated that tocilizumab infusions partially normalized inflammation of sALS patients [170]. A placebo-controlled phase II study with ALS patients who were genotyped for Asp ${ }^{358}$ Ala polymorphism of 
the IL-6 receptor gene showed that tocilizumab treatment was safe and well-tolerated and alleviated C-reactive protein (CRP) levels in CSF relevant to IL-6 receptor Asp ${ }^{358}$ Ala genotype. However, there was no difference in PBMC gene expression or clinical measures between groups [171].

Due to the efficacy of IL-1 inhibition in ALS, a single arm pilot study was performed for anakinra (Figure 12), an inhibitor of IL-1 receptor, in ALS patients. This study resulted in decreased levels of cytokines and the inflammatory marker fibrinogen during the first 24 weeks of treatment, but not in a significant reduction in disease progression [172].<smiles>C=CC1=C(C(=O)O)N2C(=O)[C@@H](NC(=O)/C(=N\OCOC(=O)C(C)(C)C)c3csc(N)n3)C2SC1</smiles>

Anakinra<smiles>CC(C)C(=O)c1c(C(C)C)nn2ccccc12</smiles>

lbudilast

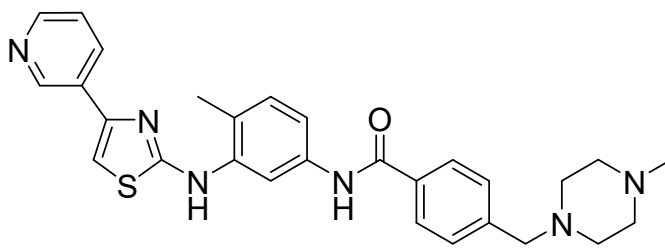

Masitinib

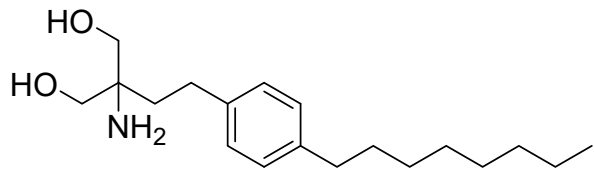

Fingolimod

Figure 12. Therapeutics against for neuroinflammation.

A colony stimulating factor $1 \mathrm{R}$ receptor (CSF1R) and c-kit inhibitor, masitinib (Figure 12), is effective against microglial, macrophage and mast cell activation. It has been given the orphan drug status and screened for treatment of various disorders [173,174]. Masitinib restrained CSF-induced proliferation, cell migration and the expression of inflammatory mediators in microglia cultures from symptomatic SOD1 ${ }^{\text {G93A }}$ spinal cords [175] and post paralysis treatment of SOD1 ${ }^{\mathrm{G} 93 \mathrm{~A}}$ mice. Masitinib also abolished mast cell and neutrophil infiltration and axonal pathology [176]. Masitinib was shown to be effective in ALS at $4.5 \mathrm{mg} / \mathrm{kg} / \mathrm{d}$ according to a double-blind study with 394 randomly-assigned ALS patients. A confirmatory phase III study will be started to confirm these findings [177].

Ibudilast (MN-166) (Figure 12), an inhibitor of macrophage migration inhibitory factor and phosphodiesterases 3, 4, 10 and 11, is capable of suppressing neuronal cell death induced by microglial activation. It was found to increase the removal of TDP-43 and SOD1 protein aggregates in transfected cellular models of ALS [178]. ALS patients who underwent ibudilast treatment up to $100 \mathrm{mg}$ /day for 36 weeks demonstrated no significant reduction in motor cortical glial activation analysed by PBR28-PET SUVR over 12-24 weeks and CNS neuroaxonal loss in an open label trial [179].

An approved immunomodulating drug for the treatment of multiple sclerosis (MS), fingolimod (Gilenya ${ }^{\circledR}$ ) (Figure 12), shows its effects by blocking egress of lymphocytes from secondary lymph organs and reducing circulating lymphocytes associated with sphingosine 1-phosphate inhibition. A phase IIa trial of ALS verified that fingolimod was safe and welltolerated and might reduce circulating lymphocytes in ALS patients. However, this trial had no statistical power to determine the effect of fingolimod on the ALSFRS-R score [180]. 


\subsection{Therapeutic Strategies against Axonal Degeneration}

The membrane protein Nogo-A is an inhibitor of neurite outgrowth that was initially identified as a potent myelin-associated inhibitor of axonal growth and regeneration [181]. Overexpressed, high amounts of Nogo-A were detected in skeletal muscles of ALS-linked mutant SOD1 mice and in patients with sALS [182]. Nogo-A causes retrograde axonal degeneration by destabilizing the neuromuscular junction in ALS [183]. Ozanezumab, an anti-Nogo-A monoclonal antibody, was found well-tolerated at single and repeat dose administration in a randomized, first-in-human clinical trial [184]. However, ozanezumab was not found to be potent, compared with placebo, in ALS patients in a double-blind, placebo-controlled, phase II trial [185].

Rho kinase (ROCK) plays an important role in the formation of high levels of actin filaments and a reduced actin turnover, leading to destruction of cell growth and axonal regeneration. Therefore, ROCK inhibition is a promising approach for ALS treatment [186]. Fasudil (Figure 13), an important ROCK inhibitor, was ascertained to slow disease progression, improve survival time and attenuate motor neuron loss in SOD1 ${ }^{\text {G93A }}$ mice [187]. A multicenter, double-blind, randomized, placebo-controlled phase IIa trial of fasudil in ALS patients also aims to assess the safety, tolerability and efficacy of fasudil at two different doses [188].<smiles>O=S(=O)(c1cccc2cnccc12)N1CCCNCC1</smiles>

\section{Fasudil}

Figure 13. Fasudil, a promising ROCK inhibitor for alleviation of axonal degeneration.

\subsection{Therapeutic Strategies against Skeletal Muscle Deterioration}

Degenerated motor neurons result in progressive muscle atrophy in ALS. Fast skeletal muscle troponin activators (FSTA) such as tirasemtiv and reldesemtiv stimulate the troponin complex, increasing its susceptibility to calcium and modulate muscle contraction $[84,183,189]$.

Tirasemtiv (Figure 14) was found to enhance rotarod performance in B6SJL-SOD1 G93A transgenic mice with functional impairment [190]. In a randomized, double-blind, placebocontrolled trial on ALS patients, no treatment effect was ascertained for tirasemtiv, whereas slow vital capacity (SVC) and muscle strength declined at less than half the rate on tirasemtiv [191]. A phase III trial on ALS patients indicated that tirasemtiv showed no effect on the decline of SVC or secondary outcome measures. In spite of this unexpected outcome, the underlying mechanism of action was investigated with reldesemtiv (Figure 14), another fast skeletal muscle troponin activator [192]. A phase II, double-blind, randomized, doseranging trial on patients with ALS indicated that reldesemtiv was well-tolerated and stable against incremental rates of decline across multiple measures of ALS progression. For this reason, a phase III trial was planned for reldesemtiv [193]. 
<smiles>C#Cc1cnc2[nH]c(=O)n(C(CC)CC)c2n1</smiles>

Tirasemtiv<smiles>NC(=O)c1ccn(-c2cnc(NC[C@]3(c4ncccc4F)C[C@H](F)C3)nc2)c1</smiles>

Reldesemtiv

Figure 14. Therapeutics against skeletal muscle deterioration.

\subsection{Therapeutic Strategies against Viruses}

Apart from the aforementioned factors, new categories such as infectious agents, including viruses, bacteria and fungi, have been recently considered. Among these agents, there is mounting evidence reporting the connection between viruses and ALS pathogenesis. Increased nonspecific reverse transcriptase activity in the blood and CSF of ALS patients compared to relatives and controls also supports this connection. In particular, retroviruses such as human immunodeficiency virus (HIV) and human T-cell leukemia virus type-1 can cause ALS-like syndrome. Hence, antiretroviral therapy could be a potential approach for retarding the symptoms of the ALS-like syndrome associated with HIV infection [194-197].

A combination of nucleoside reverse-transcriptase inhibitors lamivudine and abacavir and an HIV-1 integrase strand transfer inhibitor dolutegravir (Triumeq ${ }^{\circledR}$ ) (Figure 15) was considered to be effective in ALS treatment. An open-label phase IIa trial conducted in ALS patients revealed that long-term exposure to this combination was safe and well-tolerated in this cohort. A larger international phase III trial will be performed to investigate the effect of this combination on overall survival and ALS progression [198].<smiles>Nc1ccn([C@H]2CS[C@@H](CO)O2)c(=O)n1</smiles>

Lamivudine<smiles>Nc1nc(NC2CC2)c2ncn(C3C=CC(CO)C3)c2n1</smiles>

Abacavir<smiles>C[C@@H]1CCOC2Cn3cc(C(=O)NCc4ccc(F)cc4F)c(=O)c(O)c3C(=O)N21</smiles>

Dolutegravir

Figure 15. A potential combination of lamivudine, abacavir and dolutegravir to be effective in ALS.

\subsection{The Importance of Trophic Factors in ALS}

Trophic factors are essential for the enhancement of neuronal growth, survival and differentiation [199]. Growth factors are important for preventing motor neuron death in patients with ALS [200]. Due to its neurotrophic properties on motor neurons and the neuromuscular junction, recombinant human insulin-like growth factor I (rhIGF-I) was investigated for the determination of the relationship between rhIGF-I concentration and the prognosis of ALS. It was found that higher IGF-1 concentrations had the potential to increase survival [201]. Vascular endothelial growth factor (VEGF), a prominent factor for angiogenesis and neuroprotection, not only slowed the progression of ALS, but also increased life expectancy in SOD1 ${ }^{\mathrm{G} 93 \mathrm{~A}}$ mice [202]. Another substantial neurotrophic factor, hepatocyte growth factor (HGF), alleviated motoneuron death and axonal degeneration and extended the life span of SOD1 ${ }^{\text {G93A }}$ mice [203]. A phase I study of HGF for ALS was performed from 2011 to 2015 at Tohoku University, Japan, and a phase II study commenced in May 2016 [204].

Intriguingly, epidermal growth factor receptor (EGFR) mRNA was detected to be overexpressed 10-fold more in the spinal cord of patients with ALS, just as in SOD1 G93A transgenic mice model. Therefore, erlotinib (Figure 16), an important EGFR inhibitor, 
in particular for the treatment of EGFR mutated advanced or metastatic non-small-cell lung carcinoma (NSCLC), was tested on SOD1 ${ }^{\text {G93A }}$ mice. However, results exhibited that erlotinib could not extend survival, though it delayed the onset of multiple behavioural measures of disease progression [205].<smiles>C#Cc1cccc(Nc2ncnc3cc(OCCOC)c(OCCOC)cc23)c1</smiles>

\section{Erlotinib}

Figure 16. Erlotinib, an important EGFR inhibitor.

\subsection{Newly Synthesized and Evaluated Compounds as Anti-ALS Agents}

Chen et al. [206] defined two arylsulfanyl pyrazolone (ASP) bearing compounds, 5-((2,4-dichloro-5-methylphenylthio)methyl)-1H-pyrazol-3(2H)-one (1) and 5-((4-chloro2,5-dimethylphenylthio)methyl)- $1 H$-pyrazol-3(2H)-one (2) (Figure 17), as chemical hits by means of HTS assay expressing mutant SOD1 ${ }^{\mathrm{G} 93 \mathrm{~A}}$. Then, 5-((3,5-dichlorophenylthio)methyl)1H-pyrazol-3(2H)-one (19) (Figure 17), which was generated based on the structural optimization of ASP scaffold, was found to be more potent, with an $\mathrm{EC}_{50}$ value of $170 \mathrm{nM}$. According to pharmacokinetic assays, general parameters were amenable for compound 1, except for its relatively rapid clearance and short microsomal half-life stability features. The optimization of ASP-based compounds stands out as novel therapeutic candidates for ALS treatment.<smiles>O=c1cc(CSc2ccc(Cl)cc2Cl)[nH][nH]1</smiles>

Compound 1<smiles>Cc1cc(SCc2cc(=O)[nH][nH]2)c(C)cc1Cl</smiles>

Compound 2<smiles>O=c1cc(CSc2cc(Cl)cc(Cl)c2)[nH][nH]1</smiles>

Compound 19



CDDO-EA

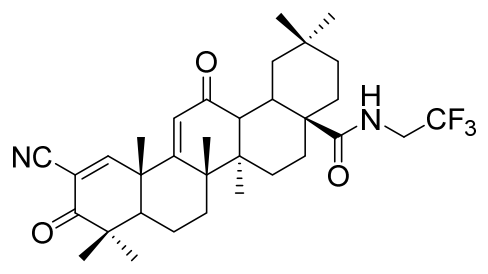

CDDO-TFEA<smiles>O=C1CC(=O)CC(c2cc(C(F)(F)F)cc(C(F)(F)F)c2)C1</smiles>

Compound 26<smiles>O=c1[nH]nc2c(NCCCc3ccncc3)cc(Cl)cn12</smiles>

JGK-263<smiles>Cc1cc(C)c(N(C)CC(=O)Nc2nc(-c3ccccn3)c[nH]2)c(C)c1</smiles>

WN1316<smiles>Cc1ccnc(COC(=O)CCCC(=O)OCCC[N+](C)(C)[O-])c1</smiles>

Compound 14

Figure 17. Newly synthesized and evaluated compounds as anti-ALS agents. 
Nrf2/ARE (NF-E2-related factor 2/antioxidant response element) signalling program has been reported to be important in the regulation of oxidative damage, neuroinflammation and mitochondrial dysfunction. CDDO (2-cyano-3,12-dioxooleana-1,9-dien-28-oic acid) ethylamide (CDDO-EA) and CDDO trifluoroethylamide (CDDO-TFEA) (Figure 17) are two synthetic triterpenoid analogs derived from oleanolic acid. It was determined that these two oleanolic acid derivatives stimulated Nrf2/ ARE in NSC-34 cell culture and in the SOD1 ${ }^{\text {G93A }}$ ALS mouse model [207].

Cyclohexane-1,3-dione (CHD) derivatives were identified based on PC12-G93A-YFP HTS assay [208]. A more efficient compound with an $\mathrm{EC}_{50}$ value of $700 \mathrm{nM}$ and more favourable pharmacokinetic profile, 5-(3,5-Bis(trifluoromethyl)phenyl)cyclohexane-1,3dione (26) (Figure 17), was obtained via the structural modification of the CHD scaffold. However, compound 26 revealed no significant activity in the mutant SOD1 ${ }^{\text {G93A }}$ mice model. These CHD analogs could be novel therapeutic candidates for further ALS studies.

A new GSK-3 $\beta$ inhibitor, 6-chloro-8-((3-(pyridin-4-yl)propyl)amino)-[1,2,4]triazolo[4,3a]pyridin-3(2H)-one (JGK-263) (Figure 17) was developed, and its improved viability and neuroprotection was determined in normal and SOD1 wild/mutant NSC34 cell lines [209]. It was also observed that JGK-263 improved motor function and delayed the time until symptom onset and death in SOD1 ${ }^{\mathrm{G} 93 \mathrm{~A}}$ ALS mice model.

Tanaka et al. [210] documented that 2-[mesityl(methyl)amino]-N-[4-(pyridin-2-yl)1H-imidazol-2-yl] acetamide trihydrochloride (WN1316) (Figure 17) selectively slowed oxidative stress-induced cell death and neuronal inflammation in the late-stage of ALS mice. WN1316, with high water solubility and BBB permeability, increased neuronal apoptosis inhibitory protein (NAIP) and Nrf2. Post-onset oral administration of low dose WN1316 improved motor function and extended the survival in SOD1 ${ }^{\mathrm{H} 46 \mathrm{R}}$ and SOD1 ${ }^{\mathrm{G} 93 \mathrm{~A}}$ ALS mice models. The results of phase I clinical trial of WN1316 (UMIN000015054) have not been published yet.

Several ester and amide derivatives of chemical chaperones were synthesized by Getter et al. [211]. Among them, 3-((5-((4,6-dimethylpyridin-2-yl)methoxy)-5-oxopentanoyl)oxy)$N, N$-dimethylpropan-1-amine oxide (14) (Figure 17) in vitro displayed both neuronal and astrocyte protection. Moreover, compound 14 improved the neurological functions and prolonged body weight loss in ALS mice.

\section{Conclusions and Future Perspectives}

ALS is a progressive and fatal motor neuron disorder. Moreover, it is a multifactorial syndrome rather than a single disease. There are several factors associated with the underlying pathogenesis of ALS, including oxidative stress (also associated with misfolding and aggregation of proteins), mitochondrial dysfunction, glutamate-induced excitotoxicity, apoptosis, neuroinflammation, axonal degeneration, skeletal muscle deterioration and viruses. Based on drug repurposing strategy, many drugs were tested in preclinical and clinical trials, but several of these trials have failed so far, owing to many reasons, such as (i) rareness of ALS causing limited participation of cohorts on trials, (ii) limited funds from pharma companies, (iii) disharmony between clinical and preclinical results, (iv) the complexity and heterogeneity features of the disease and (v) ambiguousness concerning the exact stage and region of the disease. Another main reason for the failure of clinical tests, as considered by many researchers, is as follows: When a clinical test begins, a high percentage of motor neurons have already dropped, and abnormal proteins are already accumulated in the motor neuron cell. (This is similar to Alzheimer's disease, in which symptoms are not improved after removal of the amyloid). On the other hand, these obstacles profoundly encourage researchers to find an effective cure for ALS. Thus, many studies are underway that are devoted to this purpose, utilizing cutting-edge technologies. There is an urgent need to discover new therapeutics beyond drug repurposing methods to robustly combat ALS. Due to the variety of factors involved in the onset and progression of the disease, molecular hybridization, in which different agents can be exploited simultaneously on diverse targets, can open a new door in the treatment of ALS. In particular, riluzole and 
edaravone, approved drugs for the treatment of ALS, with their simple but active pharmacophores, attract great attention for the molecular hybridization approach. In addition, different kinase inhibitors such as Src/c-Abl inhibitors (dasatinib, imatinib, bosutinib) and masitinib and rapamycin were found effective on SOD1 mutant ALS mice models and performed well in clinical studies. Among them, Src/c-Abl inhibitors account for a large portion of this class, which is attributed to their wide range of effects on reducing apoptosis, boosting autophagy and suppressing neuro-inflammation, as previously discussed. Therefore, Src/c-Abl inhibitors may offer a prominent contribution to the generation of new hybrids as promising anti-ALS drug candidates.

Author Contributions: Conceptualization, B.S., H.C., T.T., M.F. and A.N.B.; methodology, B.S., H.C., T.T., M.F. and A.N.B.; software, B.S. and H.C.; validation, B.S., H.C., T.T., M.F. and A.N.B.; formal analysis, B.S. and H.C.; investigation, B.S. and H.C.; resources, B.S. and H.C.; data curation, B.S. and H.C.; writing-original draft preparation, B.S. and H.C.; writing-review and editing, B.S., H.C., H.D., H.S., F.O., B.Y., H.T., T.T., M.O., M.F. and A.N.B.; visualization, B.S. and H.C.; supervision, B.S., H.C., T.T., M.F. and A.N.B.; project administration, B.S., H.C., T.T., M.F. and A.N.B.; funding acquisition, A.N.B. All authors have read and agreed to the published version of the manuscript.

Funding: This research was supported in part by The Scientific and Technological Research Council of Turkey (TUBITAK) under 2236 CoCirculation2 program with grant number 12C063. The entire responsibility of the publication belongs to the authors. The financial support received from TUBITAK does not mean that the content of the publication is approved in a scientific sense by TUBITAK.

Institutional Review Board Statement: Not applicable.

Informed Consent Statement: Not applicable.

Data Availability Statement: Not applicable.

Acknowledgments: Authors would like to dedicate this manuscript to memory of Fevzi Sever and Nizar Turker. We would like to express our heartfelt thanks to Suna and Inan Kiraç Foundation for their sustained support. We thank Koç University School of Medicine and College of Science for the excellent research environment created. The authors gratefully acknowledge the use of the services and facilities of the Koç University Research Center for Translational Medicine (KUTTAM), funded by the Presidency of Turkey, Presidency of Strategy and Budget. The content is solely the responsibility of the authors and does not necessarily represent the official views of the Presidency of Strategy and Budget.

Conflicts of Interest: The authors declare no conflict of interest.

\section{References}

1. Liu, J.; Wang, F. Role of neuroinflammation in amyotrophic lateral sclerosis: Cellular mechanisms and therapeutic implications. Front. Immunol. 2017, 8, 1005. [CrossRef]

2. Martinez, A.; Palomo Ruiz, M.D.; Perez, D.I.; Gil, C. Drugs in clinical development for the treatment of amyotrophic lateral sclerosis. Expert Opin. Investig. Drugs 2017, 26, 403-414. [CrossRef]

3. Gordon, P.H. Amyotrophic lateral sclerosis: Pathophysiology, diagnosis and management. CNS Drugs 2011, 25, 1-15. [CrossRef]

4. Harikrishnareddy, D.; Misra, S.; Upadhyay, S.; Modi, M.; Medhi, B. Roots to start research in amyotrophic lateral sclerosis: Molecular pathways and novel therapeutics for future. Rev. Neurosci. 2015, 26, 161-181. [CrossRef] [PubMed]

5. Sardana, D.; Zhu, C.; Zhang, M.; Gudivada, R.C.; Yang, L.; Jegga, A.G. Drug repositioning for orphan diseases. Brief. Bioinform. 2011, 12, 346-356. [CrossRef] [PubMed]

6. Longinetti, E.; Fang, F. Epidemiology of amyotrophic lateral sclerosis: An update of recent literature. Curr. Opin. Neurol. 2019, 32, 771-776. [CrossRef]

7. Root, J.; Merino, P.; Nuckols, A.; Johnson, M.; Kukar, T. Lysosome dysfunction as a cause of neurodegenerative diseases: Lessons from frontotemporal dementia and amyotrophic lateral sclerosis. Neurobiol. Dis. 2021, 154, 105360. [CrossRef]

8. Pawlyk, A.C.; Cassel, J.A.; Reitz, A.B. Current nervous system related drug targets for the treatment of amyotrophic lateral sclerosis. Curr. Pharm. Des. 2010, 16, 2053-2073. [CrossRef] [PubMed]

9. Pham, J.; Keon, M.; Brennan, S.; Saksena, N. Connecting RNA-modifying similarities of TDP-43, FUS, and SOD1 with microRNA dysregulation amidst a renewed network perspective of amyotrophic lateral sclerosis. Proteinopathy. Int. J. Mol. Sci. 2020, 21, 3464. [CrossRef]

10. Rowland, L.P.; Shneider, N.A. Amyotrophic lateral sclerosis. N. Engl. J. Med. 2001, 344, 1688-1700. [CrossRef] 
11. Bradley, W.G.; Mash, D.C. Beyond Guam: The cyanobacteria/BMAA hypothesis of the cause of ALS and other neurodegenerative diseases. Amyotroph. Lateral Scler. 2009, 2, 7-20. [CrossRef]

12. Habib, A.A.; Mitsumoto, H. Emerging drugs for amyotrophic lateral sclerosis. Expert Opin. Emerg. Drugs 2011, 16, 537-558. [CrossRef]

13. Byrne, S.; Jordan, I.; Elamin, M.; Hardiman, O. Age at onset of amyotrophic lateral sclerosis is proportional to life expectancy. Amyotroph. Lateral Scler. Front. Degener. 2013, 14, 604-607. [CrossRef]

14. Farace, C.; Fenu, G.; Lintas, S.; Oggiano, R.; Pisano, A.; Sabalic, A.; Solinas, G.; Bocca, B.; Forte, G.; Madeddu, R. Amyotrophic lateral sclerosis and lead: A systematic update. NeuroToxicology 2020, 81, 80-88. [CrossRef] [PubMed]

15. Okano, H.; Yasuda, D.; Fujimori, K.; Morimoto, S.; Takahashi, S. Ropinirole, a new ALS drug candidate developed using iPSCs. Trends Pharmacol. Sci. 2020, 41, 99-109. [CrossRef] [PubMed]

16. Costa, J.; Gomes, C.; de Carvalho, M. Diagnosis, pathogenesis and therapeutic targets in amyotrophic lateral sclerosis. CNS Neurol. Disord. Drug Targets 2010, 9, 764-778. [CrossRef] [PubMed]

17. Van Harten, A.C.M.; Phatnani, H.; Przedborski, S. Non-cell-autonomous pathogenic mechanisms in amyotrophic lateral sclerosis. Trends Neurosci. 2021, 44, 658-668. [CrossRef]

18. Nakagawa, Y.; Yamada, S. A novel hypothesis on metal dyshomeostasis and mitochondrial dysfunction in amyotrophic lateral sclerosis: Potential pathogenetic mechanism and therapeutic implications. Eur. J. Pharmacol. 2021, 892, 173737. [CrossRef]

19. Gurney, M.E.; Pu, H.; Chiu, A.Y.; Dal Canto, M.C.; Polchow, C.Y.; Alexander, D.D.; Caliendo, J.; Hentati, A.; Kwon, Y.W.; Deng, H.X.; et al. Motor neuron degeneration in mice that express a human $\mathrm{Cu}, \mathrm{Zn}$ superoxide dismutase mutation. Science 1994, 264, 1772-1775. [CrossRef]

20. Benatar, M. Lost in translation: Treatment trials in the SOD1 mouse and in human ALS. Neurobiol. Dis. 2007, 26, 1-13. [CrossRef]

21. Gomes, C.; Escrevente, C.; Costa, J. Mutant superoxide dismutase 1 overexpression in NSC-34 cells: Effect of trehalose on aggregation, TDP-43 localization and levels of co-expressed glycoproteins. Neurosci. Lett. 2010, 475, 145-149. [CrossRef]

22. Chiò, A.; Mazzini, L.; Mora, G. Disease-modifying therapies in amyotrophic lateral sclerosis. Neuropharmacology 2020, 167, 107986. [CrossRef] [PubMed]

23. Menzies, F.M.; Cookson, M.R.; Taylor, R.W.; Turnbull, D.M.; Chrzanowska-Lightowlers, Z.M.; Dong, L.; Figlewicz, D.A.; Shaw, P.J. Mitochondrial dysfunction in a cell culture model of familial amyotrophic lateral sclerosis. Brain 2002, 125, 1522-1533. [CrossRef]

24. Goos, M.; Zech, W.D.; Jaiswal, M.K.; Balakrishnan, S.; Ebert, S.; Mitchell, T.; Carrì, M.T.; Keller, B.U.; Nau, R. Expression of a Cu, Zn superoxide dismutase typical for familial amyotrophic lateral sclerosis increases the vulnerability of neuroblastoma cells to infectious injury. BMC Infect. Dis. 2007, 7, 131. [CrossRef] [PubMed]

25. Hergesheimer, R.; Lanznaster, D.; Vourc'h, P.; Andres, C.; Bakkouche, S.; Beltran, S.; Blasco, H.; Corcia, P.; Couratier, P. Advances in disease-modifying pharmacotherapies for the treatment of amyotrophic lateral sclerosis. Expert Opin. Pharmacother. 2020, 21, 1103-1110. [CrossRef]

26. Masrori, P.; Van Damme, P. Amyotrophic lateral sclerosis: A clinical review. Eur. J. Neurol. 2020, 27, 1918-1929. [CrossRef] [PubMed]

27. Behl, T.; Kaur, G.; Sehgal, A.; Bhardwaj, S.; Singh, S.; Buhas, C.; Judea-Pusta, C.; Uivarosan, D.; Munteanu, M.A.; Bungau, S Multifaceted role of matrix metalloproteinases in neurodegenerative diseases: Pathophysiological and therapeutic perspectives. Int. J. Mol. Sci. 2021, 22, 1413. [CrossRef]

28. Smart Servier Medical Art. Available online: https://smart.servier.com/ (accessed on 4 November 2021).

29. Fang, X. Potential role of gut microbiota and tissue barriers in Parkinson's disease and amyotrophic lateral sclerosis. Int. J. Neurosci. 2016, 126, 771-776. [CrossRef]

30. Wu, S.; Yi, J.; Zhang, Y.G.; Zhou, J.; Sun, J. Leaky intestine and impaired microbiome in an amyotrophic lateral sclerosis mouse model. Physiol. Rep. 2015, 3, e12356. [CrossRef]

31. Zeng, Q.; Shen, J.; Chen, K.; Zhou, J.; Liao, Q.; Lu, K.; Yuan, J.; Bi, F. The alteration of gut microbiome and metabolism in amyotrophic lateral sclerosis patients. Sci. Rep. 2020, 10, 12998. [CrossRef]

32. Niccolai, E.; Di Pilato, V.; Nannini, G.; Baldi, S.; Russo, E.; Zucchi, E.; Martinelli, I.; Menicatti, M.; Bartolucci, G.; Mandrioli, J.; et al. The gut microbiota-immunity axis in ALS: A role in deciphering disease heterogeneity? Biomedicines 2021, 9, 753. [CrossRef] [PubMed]

33. Nicholson, K.; Bjornevik, K.; Abu-Ali, G.; Chan, J.; Cortese, M.; Dedi, B.; Jeon, M.; Xavier, R.; Huttenhower, C.; Ascherio, A.; et al. The human gut microbiota in people with amyotrophic lateral sclerosis. Amyotroph. Lateral Scler. Front. Degener. 2021, 22, 186-194. [CrossRef]

34. Garbuzova-Davis, S.; Haller, E.; Saporta, S.; Kolomey, I.; Nicosia, S.V.; Sanberg, P.R. Ultrastructure of blood-brain barrier and blood-spinal cord barrier in SOD1 mice modeling ALS. Brain Res. 2007, 1157, 126-137. [CrossRef]

35. Abrahao, A.; Meng, Y.; Llinas, M.; Huang, Y.; Hamani, C.; Mainprize, T.; Aubert, I.; Heyn, C.; Black, S.E.; Hynynen, K.; et al. First-in-human trial of blood-brain barrier opening in amyotrophic lateral sclerosis using MR-guided focused ultrasound. Nat. Commun. 2019, 10, 4373. [CrossRef]

36. Barp, A.; Gerardi, F.; Lizio, A.; Sansone, V.A.; Lunetta, C. Emerging drugs for the treatment of amyotrophic lateral sclerosis: A focus on recent phase 2 trials. Expert Opin. Emerg. Drugs 2020, 25, 145-164. [CrossRef] [PubMed]

37. Jaiswal, M.K. Riluzole and edaravone: A tale of two amyotrophic lateral sclerosis drugs. Med. Res. Rev. 2019, 39, 733-748. [CrossRef] [PubMed] 
38. Chang, C.Y.; Ting, H.C.; Liu, C.A.; Su, H.L.; Chiou, T.W.; Lin, S.Z.; Harn, H.J.; Ho, T.J. Induced pluripotent stem cell (iPSC)-based neurodegenerative disease models for phenotype recapitulation and drug screening. Molecules 2020, 25, 2000. [CrossRef]

39. Vasques, J.F.; Mendez-Otero, R.; Gubert, F. Modeling ALS using iPSCs: Is it possible to reproduce the phenotypic variations observed in patients in vitro? Regen. Med. 2020, 15, 1919-1933. [CrossRef]

40. Bonaventura, G.; Iemmolo, R.; Attaguile, G.A.; La Cognata, V.; Pistone, B.S.; Raudino, G.; D’Agata, V.; Cantarella, G.; Barcellona, M.L.; Cavallaro, S. iPSCs: A preclinical drug research tool for neurological disorders. Int. J. Mol. Sci. 2021, 22, 4596. [CrossRef]

41. Ferraiuolo, L.; Maragakis, N.J. Mini-Review: Induced pluripotent stem cells and the search for new cell-specific ALS therapeutic targets. Neurosci. Lett. 2021, 755, 135911. [CrossRef]

42. Je, G.; Keyhanian, K.; Ghasemi, M. Overview of stem cells therapy in amyotrophic lateral sclerosis. Neurol. Res. 2021, 43, 616-632. [CrossRef] [PubMed]

43. Wang, L.; Yi, F.; Fu, L.; Yang, J.; Wang, S.; Wang, Z.; Suzuki, K.; Sun, L.; Xu, X.; Yu, Y.; et al. CRISPR/Cas9-mediated targeted gene correction in amyotrophic lateral sclerosis patient iPSCs. Protein Cell 2017, 8, 365-378. [CrossRef]

44. Osaki, T.; Uzel, S.G.M.; Kamm, R.D. Microphysiological 3D model of amyotrophic lateral sclerosis (ALS) from human iPS-derived muscle cells and optogenetic motor neurons. Sci. Adv. 2018, 4, eaat5847. [CrossRef]

45. Edmond, E.C.; Stagg, C.J.; Turner, M.R. Therapeutic non-invasive brain stimulation in amyotrophic lateral sclerosis: Rationale, methods and experience. J. Neurol. Neurosurg. Psychiatry 2019, 90, 1131-1138. [CrossRef]

46. Barber, S.C.; Shaw, P.J. Oxidative stress in ALS: Key role in motor neuron injury and therapeutic target. Free Radic. Biol. Med. 2010, 48, 629-641. [CrossRef]

47. Obrador, E.; Salvador, R.; López-Blanch, R.; Jihad-Jebbar, A.; Vallés, S.L.; Estrela, J.M. Oxidative stress, neuroinflammation and mitochondria in the pathophysiology of amyotrophic lateral sclerosis. Antioxidants 2020, 9, 901. [CrossRef] [PubMed]

48. Harley, J.; Clarke, B.E.; Patani, R. The interplay of RNA binding proteins, oxidative stress and mitochondrial dysfunction in ALS. Antioxidants 2021, 10, 552. [CrossRef] [PubMed]

49. Obrador, E.; Salvador-Palmer, R.; López-Blanch, R.; Jihad-Jebbar, A.; Vallés, S.L.; Estrela, J.M. The link between oxidative stress, redox status, bioenergetics and mitochondria in the pathophysiology of ALS. Int. J. Mol. Sci. 2021, 22, 6352. [CrossRef]

50. Watanabe, K.; Morinaka, Y.; Iseki, K.; Watanabe, T.; Yuki, S.; Nishi, H. Structure-activity relationship of 3-methyl-1-phenyl-2pyrazolin-5-one (edaravone). Redox Rep. 2003, 8, 151-155. [CrossRef]

51. Watanabe, K.; Tanaka, M.; Yuki, S.; Hirai, M.; Yamamoto, Y. How is edaravone effective against acute ischemic stroke and amyotrophic lateral sclerosis? J. Clin. Biochem. Nutr. 2018, 62, 20-38. [CrossRef]

52. Nakagawa, H.; Ohyama, R.; Kimata, A.; Suzuki, T.; Miyata, N. Hydroxyl radical scavenging by edaravone derivatives: Efficient scavenging by 3-methyl-1-(pyridin-2-yl)-5-pyrazolone with an intramolecular base. Bioorg. Med. Chem. Lett. 2006, 16, 5939-5942. [CrossRef]

53. Nayak, M.; Batchu, H.; Batra, S. Straightforward copper-catalyzed synthesis of pyrrolopyrazoles from halogenated pyrazolecarbaldehydes. Tetrahedron Lett. 2012, 53, 4206-4208. [CrossRef]

54. Vijay, K.; Nandi, C.; Samant, S.D. Synthesis of a dihydroquinoline based merocyanine as a 'naked eye' and 'fluorogenic' sensor for hydrazine hydrate in aqueous medium and hydrazine gas. RSC Adv. 2014, 4, 30712-30717. [CrossRef]

55. Yoshino, H.; Kimura, A. Investigation of the therapeutic effects of edaravone, a free radical scavenger, on amyotrophic lateral sclerosis (Phase II study). Amyotroph. Lateral Scler. 2006, 7, 241-245. [CrossRef]

56. Writing Group; Edaravone (MCI-186) ALS 19 Study Group. Safety and efficacy of edaravone in well defined patients with amyotrophic lateral sclerosis: A randomised, double-blind, placebo-controlled trial. Lancet Neurol. 2017, 16, 505-512. [CrossRef]

57. Takei, K.; Watanabe, K.; Yuki, S.; Akimoto, M.; Sakata, T.; Palumbo, J. Edaravone and its clinical development for amyotrophic lateral sclerosis. Amyotroph. Lateral Scler. Front. Degener. 2017, 18, 5-10. [CrossRef] [PubMed]

58. Dash, R.P.; Babu, R.J.; Srinivas, N.R. Two decades-long journey from riluzole to edaravone: Revisiting the clinical pharmacokinetics of the only two amyotrophic lateral sclerosis therapeutics. Clin. Pharmacokinet. 2018, 57, 1385-1398. [CrossRef] [PubMed]

59. Bailly, C.; Hecquet, P.E.; Kouach, M.; Thuru, X.; Goossens, J.F. Chemical reactivity and uses of 1-phenyl-3-methyl-5-pyrazolone (PMP), also known as edaravone. Bioorg. Med. Chem. 2020, 28, 115463. [CrossRef]

60. Pattee, G.L.; Post, G.R.; Gerber, R.E.; Bennett, J.P., Jr. Reduction of oxidative stress in amyotrophic lateral sclerosis following pramipexole treatment. Amyotroph. Lateral Scler. Other Mot. Neuron Disord. 2003, 4, 90-95. [CrossRef]

61. Danzeisen, R.; Schwalenstoecker, B.; Gillardon, F.; Buerger, E.; Krzykalla, V.; Klinder, K.; Schild, L.; Hengerer, B.; Ludolph, A.C.; Dorner-Ciossek, C.; et al. Targeted antioxidative and neuroprotective properties of the dopamine agonist pramipexole and its nondopaminergic enantiomer SND ${ }_{919}$ CL2x [(+)2-amino-4,5,6,7-tetrahydro-6-Lpropylamino-benzathiazole dihydrochloride]. J. Pharmacol. Exp. Ther. 2006, 316, 189-199. [CrossRef]

62. Cudkowicz, M.E.; van den Berg, L.H.; Shefner, J.M.; Mitsumoto, H.; Mora, J.S.; Ludolph, A.; Hardiman, O.; Bozik, M.E.; Ingersoll, E.W.; Archibald, D.; et al. Dexpramipexole versus placebo for patients with amyotrophic lateral sclerosis (EMPOWER): A randomised, double-blind, phase 3 trial. Lancet Neurol. 2013, 12, 1059-1067. [CrossRef]

63. Cudkowicz, M.; Bozik, M.E.; Ingersoll, E.W.; Miller, R.; Mitsumoto, H.; Shefner, J.; Moore, D.H.; Schoenfeld, D.; Mather, J.L.; Archibald, D.; et al. The effects of dexpramipexole (KNS-760704) in individuals with amyotrophic lateral sclerosis. Nat. Med. 2011, 17, 1652-1656. [CrossRef] [PubMed] 
64. Tanaka, K.; Kanno, T.; Yanagisawa, Y.; Yasutake, K.; Hadano, S.; Yoshii, F.; Ikeda, J.E. Bromocriptine methylate suppresses glial inflammation and moderates disease progression in a mouse model of amyotrophic lateral sclerosis. Exp. Neurol. 2011, $232,41-52$. [CrossRef] [PubMed]

65. Nagata, E.; Ogino, M.; Iwamoto, K.; Kitagawa, Y.; Iwasaki, Y.; Yoshii, F.; Ikeda, J.E.; ALS Consortium Investigators. Bromocriptine mesylate attenuates amyotrophic lateral sclerosis: A phase $2 a$, randomized, double-blind, placebo-controlled research in Japanese patients. PLOS ONE 2016, 11, e0149509. [CrossRef] [PubMed]

66. Fujimori, K.; Ishikawa, M.; Otomo, A.; Atsuta, N.; Nakamura, R.; Akiyama, T.; Hadano, S.; Aoki, M.; Saya, H.; Sobue, G.; et al. Modeling sporadic ALS in iPSC-derived motor neurons identifies a potential therapeutic agent. Nat. Med. 2018, 24, 1579-1589. [CrossRef] [PubMed]

67. Morimoto, S.; Takahashi, S.; Fukushima, K.; Saya, H.; Suzuki, N.; Aoki, M.; Okano, H.; Nakahara, J. Ropinirole hydrochloride remedy for amyotrophic lateral sclerosis - Protocol for a randomized, double-blind, placebo-controlled, single-center, and open-label continuation phase I/IIa clinical trial (ROPALS trial). Regen. Ther. 2019, 11, 143-166. [CrossRef]

68. Bucchia, M.; Ramirez, A.; Parente, V.; Simone, C.; Nizzardo, M.; Magri, F.; Dametti, S.; Corti, S. Therapeutic development in amyotrophic lateral sclerosis. Clin. Ther. 2015, 37, 668-680. [CrossRef]

69. Waibel, S.; Reuter, A.; Malessa, S.; Blaugrund, E.; Ludolph, A.C. Rasagiline alone and in combination with riluzole prolongs survival in an ALS mouse model. J. Neurol. 2004, 251, 1080-1084. [CrossRef]

70. Ludolph, A.C.; Schuster, J.; Dorst, J.; Dupuis, L.; Dreyhaupt, J.; Weishaupt, J.H.; Kassubek, J.; Weiland, U.; Petri, S.; Meyer, T.; et al. Safety and efficacy of rasagiline as an add-on therapy to riluzole in patients with amyotrophic lateral sclerosis: A randomised, double-blind, parallel-group, placebo-controlled, phase 2 trial. Lancet Neurol. 2018, 17, 681-688. [CrossRef]

71. Statland, J.M.; Moore, D.; Wang, Y.; Walsh, M.; Mozaffar, T.; Elman, L.; Nations, S.P.; Mitsumoto, H.; Fernandes, J.A.; Saperstein, D.; et al. Rasagiline for amyotrophic lateral sclerosis: A randomized, controlled trial. Muscle Nerve 2019, 59, 201-207. [CrossRef]

72. Lange, D.J.; Murphy, P.L.; Diamond, B.; Appel, V.; Lai, E.C.; Younger, D.S.; Appel, S.H. Selegiline is ineffective in a collaborative double-blind, placebo-controlled trial for treatment of amyotrophic lateral sclerosis. Arch. Neurol. 1998, 55, 93-96. [CrossRef] [PubMed]

73. Luo, F.; Sandhu, A.F.; Rungratanawanich, W.; Williams, G.E.; Akbar, M.; Zhou, S.; Song, B.J.; Wang, X. Melatonin and autophagy in aging-related neurodegenerative diseases. Int. J. Mol. Sci. 2020, 21, 7174. [CrossRef] [PubMed]

74. Weishaupt, J.H.; Bartels, C.; Pölking, E.; Dietrich, J.; Rohde, G.; Poeggeler, B.; Mertens, N.; Sperling, S.; Bohn, M.; Hüther, G.; et al. Reduced oxidative damage in ALS by high-dose enteral melatonin treatment. J. Pineal Res. 2006, 41, 313-323. [CrossRef]

75. Bald, E.M.; Nance, C.S.; Schultz, J.L. Melatonin may slow disease progression in amyotrophic lateral sclerosis: Findings from the pooled resource open-access ALS clinic trials database. Muscle Nerve 2021, 63, 572-576. [CrossRef]

76. Choi, E.S.; Dokholyan, N.V. SOD1 oligomers in amyotrophic lateral sclerosis. Curr. Opin. Struct. Biol. 2021, 66, 225-230. [CrossRef] [PubMed]

77. Eleutherio, E.C.A.; Silva Magalhães, R.S.; de Araújo Brasil, A.; Monteiro Neto, J.R.; de Holanda Paranhos, L. SOD1, more than just an antioxidant. Arch. Biochem. Biophys. 2021, 697, 108701. [CrossRef]

78. Smith, R.A.; Milleri, T.M.; Yamanaka, K.; Monia, B.P.; Condon, T.P.; Hung, G.; Lobsiger, C.S.; Ward, C.M.; McAlonis-Downes, M.; Wei, H.; et al. Antisense oligonucleotide therapy for neurodegenerative disease. J. Clin. Investig. 2006, 116, 2290-2296. [CrossRef]

79. Miller, T.M.; Pestronk, A.; David, W.; Rothstein, J.; Simpson, E.; Appel, S.H.; Andres, P.L.; Mahoney, K.; Allred, P.; Alexander, K.; et al. An antisense oligonucleotide against SOD1 delivered intrathecally for patients with SOD1 familial amyotrophic lateral sclerosis: A phase 1, randomised, first-in-man study. Lancet Neurol. 2013, 12, 435-442. [CrossRef]

80. Miller, T.; Cudkowitz, M.; Shaw, P. Safety, PK, PD, and exploratory efficacy in single and multiple dose study of a SOD1 antisense oligonucleotide (BIIB067) administered to participants with ALS. In Proceedings of the American Academy of Neurology 71st Annual Meeting, Philadelphia, PA, USA, 4-10 May 2019.

81. Kieran, D.; Kalmar, B.; Dick, J.R.; Riddoch-Contreras, J.; Burnstock, G.; Greensmith, L. Treatment with arimoclomol, a coinducer of heat shock proteins, delays disease progression in ALS mice. Nat. Med. 2004, 10, 402-405. [CrossRef]

82. Kalmar, B.; Lu, C.H.; Greensmith, L. The role of heat shock proteins in Amyotrophic Lateral Sclerosis: The therapeutic potential of Arimoclomol. Pharmacol. Ther. 2014, 141, 40-54. [CrossRef]

83. Benatar, M.; Wuu, J.; Andersen, P.M.; Atassi, N.; David, W.; Cudkowicz, M.; Schoenfeld, D. Randomized, double-blind, placebocontrolled trial of arimoclomol in rapidly progressive SOD1 ALS. Neurology 2018, 90, e565-e574. [CrossRef]

84. Liscic, R.M.; Alberici, A.; Cairns, N.J.; Romano, M.; Buratti, E. From basic research to the clinic: Innovative therapies for ALS and FTD in the pipeline. Mol. Neurodegener. 2020, 15, 31. [CrossRef] [PubMed]

85. Crippa, V.; D’Agostino, V.G.; Cristofani, R.; Rusmini, P.; Cicardi, M.E.; Messi, E.; Loffredo, R.; Pancher, M.; Piccolella, M.; Galbiati, M.; et al. Transcriptional induction of the heat shock protein B8 mediates the clearance of misfolded proteins responsible for motor neuron diseases. Sci. Rep. 2016, 6, 22827. [CrossRef] [PubMed]

86. Mandrioli, J.; Crippa, V.; Cereda, C.; Bonetto, V.; Zucchi, E.; Gessani, A.; Ceroni, M.; Chio, A.; D’Amico, R.; Monsurrò, M.R.; et al. Proteostasis and ALS: Protocol for a phase II, randomised, double-blind, placebo-controlled, multicentre clinical trial for colchicine in ALS (Co-ALS). BMJ Open. 2019, 9, e028486. [CrossRef]

87. Nikseresht, S.; Hilton, J.B.W.; Kysenius, K.; Liddell, J.R.; Crouch, P.J. Copper-ATSM as a treatment for ALS: Support from mutant SOD1 models and beyond. Life 2020, 10, 271. [CrossRef] [PubMed] 
88. McAllum, E.J.; Lim, N.K.; Hickey, J.L.; Paterson, B.M.; Donnelly, P.S.; Li, Q.X.; Liddell, J.R.; Barnham, K.J.; White, A.R.; Crouch, P.J. Therapeutic effects of CuII(atsm) in the SOD1-G37R mouse model of amyotrophic lateral sclerosis. Amyotroph. Lateral Scler. Front. Degener. 2013, 14, 586-590. [CrossRef]

89. Hilton, J.B.W.; Kysenius, K.; Liddell, J.R.; Rautengarten, C.; Mercer, S.W.; Paul, B.; Beckman, J.S.; McLean, C.; White, A.R.; Donnelly, P.S.; et al. Disrupted copper availability in sporadic ALS: Implications for CuII(atsm) as a treatment option. BioRxiv 2020. [CrossRef]

90. Lange, D.J.; Andersen, P.M.; Remanan, R.; Marklund, S.; Benjamin, D. Pyrimethamine decreases levels of SOD1 in leukocytes and cerebrospinal fluid of ALS patients: A phase I pilot study. Amyotroph. Lateral Scler. Front. Degener. 2013, 14, 199-204. [CrossRef]

91. Lange, D.J.; Shahbazi, M.; Silani, V.; Ludolph, A.C.; Weishaupt, J.H.; Ajroud-Driss, S.; Fields, K.G.; Remanan, R.; Appel, S.H.; Morelli, C.; et al. Pyrimethamine significantly lowers cerebrospinal fluid $\mathrm{Cu} / \mathrm{Zn}$ superoxide dismutase in amyotrophic lateral sclerosis patients with SOD1 mutations. Ann. Neurol. 2017, 81, 837-848. [CrossRef]

92. Capper, M.J.; Wright, G.S.A.; Barbieri, L.; Luchinat, E.; Mercatelli, E.; McAlary, L.; Yerbury, J.J.; O’Neill, P.M.; Antonyuk, S.V.; Banci, L.; et al. The cysteine-reactive small molecule ebselen facilitates effective SOD1 maturation. Nat. Commun. 2018, 9, 1693. [CrossRef]

93. Jhanji, R.; Behl, T.; Sehgal, A.; Bungau, S. Mitochondrial dysfunction and traffic jams in amyotrophic lateral sclerosis. Mitochondrion 2021, 58, 102-110. [CrossRef] [PubMed]

94. Bordet, T.; Buisson, B.; Michaud, M.; Drouot, C.; Galéa, P.; Delaage, P.; Akentieva, N.P.; Evers, A.S.; Covey, D.F.; Ostuni, M.A.; et al. Identification and characterization of cholest-4-en-3-one, oxime (TRO19622), a novel drug candidate for amyotrophic lateral sclerosis. J. Pharmacol. Exp. Ther. 2007, 322, 709-720. [CrossRef] [PubMed]

95. Lenglet, T.; Lacomblez, L.; Abitbol, J.L.; Ludolph, A.; Mora, J.S.; Robberecht, W.; Shaw, P.J.; Pruss, R.M.; Cuvier, V.; Meininger, V.; et al. A phase II-III trial of olesoxime in subjects with amyotrophic lateral sclerosis. Eur. J. Neurol. 2014, 21, 529-536. [CrossRef]

96. Klivenyi, P.; Ferrante, R.J.; Matthews, R.T.; Bogdanov, M.B.; Klein, A.M.; Andreassen, O.A.; Mueller, G.; Wermer, M.; KaddurahDaouk, R.; Beal, M.F. Neuroprotective effects of creatine in a transgenic animal model of amyotrophic lateral sclerosis. Nat. Med. 1999, 5, 347-350. [CrossRef] [PubMed]

97. Groeneveld, G.J.; Veldink, J.H.; van der Tweel, I.; Kalmijn, S.; Beijer, C.; de Visser, M.; Wokke, J.H.; Franssen, H.; van den Berg, L.H. A randomized sequential trial of creatine in amyotrophic lateral sclerosis. Ann. Neurol. 2003, 53, 437-445. [CrossRef] [PubMed]

98. Shefner, J.M.; Cudkowicz, M.E.; Schoenfeld, D.; Conrad, T.; Taft, J.; Chilton, M.; Urbinelli, L.; Qureshi, M.; Zhang, H.; Pestronk, A.; et al. A clinical trial of creatine in ALS. Neurology 2004, 63, 1656-1661. [CrossRef]

99. Rosenfeld, J.; King, R.M.; Jackson, C.E.; Bedlack, R.S.; Barohn, R.J.; Dick, A.; Phillips, L.H.; Chapin, J.; Gelinas, D.F.; Lou, J.S. Creatine monohydrate in ALS: Effects on strength, fatigue, respiratory status and ALSFRS. Amyotroph. Lateral Scler. 2008, 9 , 266-272. [CrossRef]

100. Matthews, R.T.; Yang, L.; Browne, S.; Baik, M.; Beal, M.F. Coenzyme Q10 administration increases brain mitochondrial concentrations and exerts neuroprotective effects. Proc. Natl. Acad. Sci. USA 1998, 95, 8892-8897. [CrossRef]

101. Kaufmann, P.; Thompson, J.L.; Levy, G.; Buchsbaum, R.; Shefner, J.; Krivickas, L.S.; Katz, J.; Rollins, Y.; Barohn, R.J.; Jackson, C.E.; et al. Phase II trial of CoQ10 for ALS finds insufficient evidence to justify phase III. Ann. Neurol. 2009, 66, 235-244. [CrossRef]

102. Ramalho, T.C.; de Castro, A.A.; Tavares, T.S.; Silva, M.C.; Silva, D.R.; Cesar, P.H.; Santos, L.A.; da Cunha, E.F.F.; Nepovimova, E.; Kuca, K. Insights into the pharmaceuticals and mechanisms of neurological orphan diseases: Current status and future expectations. Prog. Neurobiol. 2018, 169, 135-157. [CrossRef]

103. Ng Kee Kwong, K.C.; Mehta, A.R.; Nedergaard, M.; Chandran, S. Defining novel functions for cerebrospinal fluid in ALS pathophysiology. Acta Neuropathol. Commun. 2020, 8, 140. [CrossRef] [PubMed]

104. Silva-Hucha, S.; Pastor, A.M.; Morcuende, S. Neuroprotective effect of vascular endothelial growth factor on motoneurons of the oculomotor system. Int. J. Mol. Sci. 2021, 22, 814. [CrossRef] [PubMed]

105. Cheah, B.C.; Vucic, S.; Krishnan, A.V.; Kiernan, M.C. Riluzole, neuroprotection and amyotrophic lateral sclerosis. Curr. Med. Chem. 2010, 17, 1942-1959. [CrossRef]

106. Mignani, S.; Majoral, J.P.; Desaphy, J.F.; Lentini, G. From Riluzole to dexpramipexole via substituted-benzothiazole derivatives for amyotrophic lateral sclerosis disease treatment: Case studies. Molecules 2020, 25, 3320. [CrossRef]

107. Mathis, S.; Couratier, P.; Julian, A.; Vallat, J.M.; Corcia, P.; Le Masson, G. Management and therapeutic perspectives in amyotrophic lateral sclerosis. Expert Rev. Neurother. 2017, 17, 263-276. [CrossRef] [PubMed]

108. Bensimon, G.; Lacomblez, L.; Meininger, V. ALS/Riluzole Study Group. A controlled trial of riluzole in amyotrophic lateral sclerosis. N. Engl. J. Med. 1994, 330, 585-591. [CrossRef]

109. Lacomblez, L.; Bensimon, G.; Leigh, P.N.; Guillet, P.; Powe, L.; Durrleman, S.; Delumeau, J.C.; Meininger, V. A confirmatory dose-ranging study of riluzole in ALS. ALS/Riluzole Study Group-II. Neurology 1996, 47, S242-S250. [CrossRef]

110. Dorst, J.; Ludolph, A.C.; Huebers, A. Disease-modifying and symptomatic treatment of amyotrophic lateral sclerosis. Ther. Adv. Neurol. Disord. 2017, 11, 1756285617734734. [CrossRef]

111. Kumar, V.; Islam, A.; Hassan, M.I.; Ahmad, F. Therapeutic progress in amyotrophic lateral sclerosis-beginning to learning. Eur. J. Med. Chem. 2016, 121, 903-917. [CrossRef]

112. Miller, R.G.; Moore, D.H., 2nd; Gelinas, D.F.; Dronsky, V.; Mendoza, M.; Barohn, R.J.; Bryan, W.; Ravits, J.; Yuen, E.; Neville, H.; et al. Phase III randomized trial of gabapentin in patients with amyotrophic lateral sclerosis. Neurology 2001, 56, 843-848. [CrossRef] 
113. Errante, L.D.; Petroff, O.A. Acute effects of gabapentin and pregabalin on rat forebrain cellular GABA, glutamate, and glutamine concentrations. Seizure 2003, 12, 300-306. [CrossRef]

114. Cudkowicz, M.E.; Shefner, J.M.; Schoenfeld, D.A.; Brown, R.H., Jr.; Johnson, H.; Qureshi, M.; Jacobs, M.; Rothstein, J.D.; Appel, S.H.; Pascuzzi, R.M.; et al. A randomized, placebo-controlled trial of topiramate in amyotrophic lateral sclerosis. Neurology 2003, 61, 456-464. [CrossRef]

115. Lanka, V.; Cudkowicz, M. Therapy development for ALS: Lessons learned and path forward. Amyotroph. Lateral Scler. 2008, 9 , 131-140. [CrossRef]

116. Akamatsu, M.; Yamashita, T.; Hirose, N.; Teramoto, S.; Kwak, S. The AMPA receptor antagonist perampanel robustly rescues amyotrophic lateral sclerosis (ALS) pathology in sporadic ALS model mice. Sci. Rep. 2016, 6, 28649. [CrossRef]

117. Hotait, M.; Ismail, H.H.; Saab, G.E.; Salameh, J.S. An open label pilot study of the safety and tolerability of perampanel in amyotrophic lateral sclerosis. Muscle Nerve 2021, 64, 504-508. [CrossRef]

118. Aizawa, H.; Kato, H.; Oba, K.; Kawahara, T.; Okubo, Y.; Saito, T.; Naito, M.; Urushitani, M.; Tamaoka, A.; Nakamagoe, K.; et al Randomized phase 2 study of perampanel for sporadic amyotrophic lateral sclerosis. J. Neurol. 2022, 269, 885-896. [CrossRef] [PubMed]

119. Paizs, M.; Tortarolo, M.; Bendotti, C.; Engelhardt, J.I.; Siklós, L. Talampanel reduces the level of motoneuronal calcium in transgenic mutant SOD1 mice only if applied presymptomatically. Amyotroph. Lateral Scler. 2011, 12, 340-344. [CrossRef]

120. Pascuzzi, R.M.; Shefner, J.; Chappell, A.S.; Bjerke, J.S.; Tamura, R.; Chaudhry, V.; Clawson, L.; Haas, L.; Rothstein, J.D. A phase II trial of talampanel in subjects with amyotrophic lateral sclerosis. Amyotroph. Lateral Scler. 2010, 11, 266-271. [CrossRef] [PubMed]

121. Wang, R.; Zhang, D. Memantine prolongs survival in an amyotrophic lateral sclerosis mouse model. Eur. J. Neurosci. 2005, 22, 2376-2380. [CrossRef]

122. De Carvalho, M.; Pinto, S.; Costa, J.; Evangelista, T.; Ohana, B.; Pinto, A. A randomized, placebo-controlled trial of memantine for functional disability in amyotrophic lateral sclerosis. Amyotroph. Lateral Scler. 2010, 11, 456-460. [CrossRef]

123. Gredal, O.; Werdelin, L.; Bak, S.; Christensen, P.B.; Boysen, G.; Kristensen, M.O.; Jespersen, J.H.; Regeur, L.; Hinge, H.H.; Jensen, T.S. A clinical trial of dextromethorphan in amyotrophic lateral sclerosis. Acta Neurol. Scand. 1997, 96, 8-13. [CrossRef]

124. Brimson, J.M.; Brimson, S.; Chomchoei, C.; Tencomnao, T. Using sigma-ligands as part of a multi-receptor approach to target diseases of the brain. Expert Opin. Ther. Targets 2020, 24, 1009-1028. [CrossRef] [PubMed]

125. Huynh, W.; Ahmed, R.; Mahoney, C.J.; Nguyen, C.; Tu, S.; Caga, J.; Loh, P.; Lin, C.S.; Kiernan, M.C. The impact of cognitive and behavioral impairment in amyotrophic lateral sclerosis. Expert Rev. Neurother. 2020, 20, 281-293. [CrossRef] [PubMed]

126. Rothstein, J.D.; Patel, S.; Regan, M.R.; Haenggeli, C.; Huang, Y.H.; Bergles, D.E.; Jin, L.; Dykes Hoberg, M.; Vidensky, S.; Chung, D.S.; et al. Beta-lactam antibiotics offer neuroprotection by increasing glutamate transporter expression. Nature 2005, 433, 73-77. [CrossRef] [PubMed]

127. Cudkowicz, M.E.; Titus, S.; Kearney, M.; Yu, H.; Sherman, A.; Schoenfeld, D.; Hayden, D.; Shui, A.; Brooks, B.; Conwit, R.; et al Safety and efficacy of ceftriaxone for amyotrophic lateral sclerosis: A multi-stage, randomised, double-blind, placebo-controlled trial. Lancet Neurol. 2014, 13, 1083-1091. [CrossRef]

128. Yacila, G.; Sari, Y. Potential therapeutic drugs and methods for the treatment of amyotrophic lateral sclerosis. Curr. Med. Chem. 2014, 21, 3583-3593. [CrossRef]

129. Miller, R.G.; Smith, S.A.; Murphy, J.R.; Brinkmann, J.R.; Graves, J.; Mendoza, M.; Sands, M.L.; Ringel, S.P. A clinical trial of verapamil in amyotrophic lateral sclerosis. Muscle Nerve 1996, 19, 511-515. [CrossRef]

130. Miller, R.G.; Shepherd, R.; Dao, H.; Khramstov, A.; Mendoza, M.; Graves, J.; Smith, S. Controlled trial of nimodipine in amyotrophic lateral sclerosis. Neuromuscul. Disord. 1996, 6, 101-104. [CrossRef]

131. Shibuya, K.; Misawa, S.; Kimura, H.; Noto, Y.; Sato, Y.; Sekiguchi, Y.; Iwai, Y.; Mitsuma, S.; Beppu, M.; Watanabe, K.; et al. A single blind randomized controlled clinical trial of mexiletine in amyotrophic lateral sclerosis: Efficacy and safety of sodium channel blocker phase II trial. Amyotroph. Lateral Scler. Front. Degener. 2015, 16, 353-358. [CrossRef]

132. Weiss, M.D.; Macklin, E.A.; Simmons, Z.; Knox, A.S.; Greenblatt, D.J.; Atassi, N.; Graves, M.; Parziale, N.; Salameh, J.S.; Quinn, C.; et al. A randomized trial of mexiletine in ALS: Safety and effects on muscle cramps and progression. Neurology 2016, 86, 1474-1481. [CrossRef]

133. Oskarsson, B.; Moore, D.; Mozaffar, T.; Ravits, J.; Wiedau-Pazos, M.; Parziale, N.; Joyce, N.C.; Mandeville, R.; Goyal, N.; Cudkowicz, M.E.; et al. Mexiletine for muscle cramps in amyotrophic lateral sclerosis: A randomized, double-blind crossover trial. Muscle Nerve 2018, 58, 42-48. [CrossRef]

134. Goldsmith, D.R.; Wagstaff, A.J.; Ibbotson, T.; Perry, C.M. Lamotrigine: A review of its use in bipolar disorder. Drugs 2003, 63, 2029-2050. [CrossRef]

135. Ryberg, H.; Askmark, H.; Persson, L.I. A double-blind randomized clinical trial in amyotrophic lateral sclerosis using lamotrigine: Effects on CSF glutamate, aspartate, branched-chain amino acid levels and clinical parameters. Acta Neurol. Scand. 2003, 108, 1-8. [CrossRef] [PubMed]

136. Beattie, K.; Phadke, G.; Novakovic, J. Lamotrigine. In Profiles of Drug Substances, Excipients and Related Methodology; Brittain, H.G., Ed.; Elsevier: Amsterdam, The Netherlands, 2012; Volume 37, pp. 245-285.

137. Wainger, B.J.; Kiskinis, E.; Mellin, C.; Wiskow, O.; Han, S.S.; Sandoe, J.; Perez, N.P.; Williams, L.A.; Lee, S.; Boulting, G.; et al. Intrinsic membrane hyperexcitability of amyotrophic lateral sclerosis patient-derived motor neurons. Cell Rep. 2014, 7, 1-11. [CrossRef] 
138. Wainger, B.J.; Macklin, E.A.; Vucic, S.; McIlduff, C.E.; Paganoni, S.; Maragakis, N.J.; Bedlack, R.; Goyal, N.A.; Rutkove, S.B.; Lange, D.J.; et al. Effect of ezogabine on cortical and spinal motor neuron excitability in amyotrophic lateral sclerosis: A randomized clinical trial. JAMA Neurol. 2021, 78, 186-196. [CrossRef] [PubMed]

139. Kaji, R.; Kodama, M.; Imamura, A.; Hashida, T.; Kohara, N.; Ishizu, M.; Inui, K.; Kimura, J. Effect of ultrahigh-dose methylcobalamin on compound muscle action potentials in amyotrophic lateral sclerosis: A double-blind controlled study. Muscle Nerve 1998, 21, 1775-1778. [CrossRef]

140. Ikeda, K.; Iwasaki, Y.; Kaji, R. Neuroprotective effect of ultra-high dose methylcobalamin in wobbler mouse model of amyotrophic lateral sclerosis. J. Neurol. Sci. 2015, 354, 70-74. [CrossRef]

141. Kaji, R.; Imai, T.; Iwasaki, Y.; Okamoto, K.; Nakagawa, M.; Ohashi, Y.; Takase, T.; Hanada, T.; Shimizu, H.; Tashiro, K.; et al. Ultrahigh-dose methylcobalamin in amyotrophic lateral sclerosis: A long-term phase II/III randomised controlled study. J. Neurol. Neurosurg. Psychiatry 2019, 90, 451-457. [CrossRef]

142. Levine, B.; Sinha, S.; Kroemer, G. Bcl-2 family members: Dual regulators of apoptosis and autophagy. Autophagy 2008, 4, 600-606 [CrossRef]

143. Amin, A.; Perera, N.D.; Beart, P.M.; Turner, B.J.; Shabanpoor, F. Amyotrophic lateral sclerosis and autophagy: Dysfunction and therapeutic targeting. Cells 2020, 9, 2413. [CrossRef]

144. Wang, J. Regulation of cell death by the Abl tyrosine kinase. Oncogene 2000, 19, 5643-5650. [CrossRef] [PubMed]

145. Schlatterer, S.D.; Acker, C.M.; Davies, P. c-Abl in neurodegenerative disease. J. Mol. Neurosci. 2011, 45, 445-452. [CrossRef] [PubMed]

146. Karagiannis, P.; Inoue, H. ALS, a cellular whodunit on motor neuron degeneration. Mol. Cell Neurosci. 2020, $107,103524$. [CrossRef] [PubMed]

147. Kim, B.W.; Jeong, Y.E.; Wong, M.; Martin, L.J. DNA damage accumulates and responses are engaged in human ALS brain and spinal motor neurons and DNA repair is activatable in iPSC-derived motor neurons with SOD1 mutations. Acta Neuropathol. Commun. 2020, 8, 7. [CrossRef]

148. Rojas, F.; Gonzalez, D.; Cortes, N.; Ampuero, E.; Hernández, D.E.; Fritz, E.; Abarzua, S.; Martinez, A.; Elorza, A.A.; Alvarez, A.; et al. Reactive oxygen species trigger motoneuron death in non-cell-autonomous models of ALS through activation of c-Abl signaling. Front. Cell Neurosci. 2015, 9, 203. [CrossRef]

149. Katsumata, R.; Ishigaki, S.; Katsuno, M.; Kawai, K.; Sone, J.; Huang, Z.; Adachi, H.; Tanaka, F.; Urano, F.; Sobue, G. c-Abl inhibition delays motor neuron degeneration in the G93A mouse, an animal model of amyotrophic lateral sclerosis. PLoS ONE 2012, 7, e46185. [CrossRef]

150. Imamura, K.; Izumi, Y.; Watanabe, A.; Tsukita, K.; Woltjen, K.; Yamamoto, T.; Hotta, A.; Kondo, T.; Kitaoka, S.; Ohta, A.; et al. The $\mathrm{Src} / \mathrm{c}-\mathrm{Abl}$ pathway is a potential therapeutic target in amyotrophic lateral sclerosis. Sci. Transl. Med. 2017, 9, eaaf3962. [CrossRef]

151. Imamura, K.; Izumi, Y.; Banno, H.; Uozumi, R.; Morita, S.; Egawa, N.; Ayaki, T.; Nagai, M.; Nishiyama, K.; Watanabe, Y.; et al Induced pluripotent stem cell-based Drug Repurposing for Amyotrophic lateral sclerosis Medicine (iDReAM) study: Protocol for a phase I dose escalation study of bosutinib for amyotrophic lateral sclerosis patients. BMJ Open 2019, 9, e033131. [CrossRef]

152. Amaral, J.D.; Viana, R.J.; Ramalho, R.M.; Steer, C.J.; Rodrigues, C.M. Bile acids: Regulation of apoptosis by ursodeoxycholic acid. J. Lipid Res. 2009, 50, 1721-1734. [CrossRef]

153. Elia, A.E.; Lalli, S.; Monsurrò, M.R.; Sagnelli, A.; Taiello, A.C.; Reggiori, B.; La Bella, V.; Tedeschi, G.; Albanese, A. Tauroursodeoxycholic acid in the treatment of patients with amyotrophic lateral sclerosis. Eur. J. Neurol. 2016, 23, 45-52. [CrossRef]

154. Palomo, V.; Nozal, V.; Rojas-Prats, E.; Gil, C.; Martinez, A. Protein kinase inhibitors for amyotrophic lateral sclerosis therapy. Br. J. Pharmacol. 2021, 178, 1316-1335. [CrossRef]

155. Mandrioli, J.; D'Amico, R.; Zucchi, E.; Gessani, A.; Fini, N.; Fasano, A.; Caponnetto, C.; Chiò, A.; Dalla Bella, E.; Lunetta, C.; et al. Rapamycin treatment for amyotrophic lateral sclerosis: Protocol for a phase II randomized, double-blind, placebo-controlled, multicenter, clinical trial (RAP-ALS trial). Medicine 2018, 97, e11119. [CrossRef]

156. Fornai, F.; Longone, P.; Cafaro, L.; Kastsiuchenka, O.; Ferrucci, M.; Manca, M.L.; Lazzeri, G.; Spalloni, A.; Bellio, N.; Lenzi, P.; et al. Lithium delays progression of amyotrophic lateral sclerosis. Proc. Natl. Acad. Sci. USA 2008, 105, 2052-2057. [CrossRef] [PubMed]

157. Morrison, K.E.; Dhariwal, S.; Hornabrook, R.; Savage, L.; Burn, D.J.; Khoo, T.K.; Kelly, J.; Murphy, C.L.; Al-Chalabi, A.; et al.; UKMND-LiCALS Study Group. Lithium in patients with amyotrophic lateral sclerosis (LiCALS): A phase 3 multicentre, randomised, double-blind, placebo-controlled trial. Lancet Neurol. 2013, 12, 339-345.

158. Aggarwal, S.P.; Zinman, L.; Simpson, E.; McKinley, J.; Jackson, K.E.; Pinto, H.; Kaufman, P.; Conwit, R.A.; Schoenfeld, D.; Shefner, J.; et al. Safety and efficacy of lithium in combination with riluzole for treatment of amyotrophic lateral sclerosis: A randomised, double-blind, placebo-controlled trial. Lancet Neurol. 2010, 9, 481-488. [CrossRef]

159. Sugai, F.; Yamamoto, Y.; Miyaguchi, K.; Zhou, Z.; Sumi, H.; Hamasaki, T.; Goto, M.; Sakoda, S. Benefit of valproic acid in suppressing disease progression of ALS model mice. Eur. J. Neurosci. 2004, 20, 3179-3183. [CrossRef]

160. Piepers, S.; Veldink, J.H.; de Jong, S.W.; van der Tweel, I.; van der Pol, W.L.; Uijtendaal, E.V.; Schelhaas, H.J.; Scheffer, H.; de Visser, M.; de Jong, J.M.; et al. Randomized sequential trial of valproic acid in amyotrophic lateral sclerosis. Ann. Neurol. 2009, 66, 227-234. [CrossRef] [PubMed]

161. Leng, Y.; Liang, M.H.; Ren, M.; Marinova, Z.; Leeds, P.; Chuang, D.M. Synergistic neuroprotective effects of lithium and valproic acid or other histone deacetylase inhibitors in neurons: Roles of glycogen synthase kinase-3 inhibition. J. Neurosci. 2008, 28, 2576-2588. [CrossRef] 
162. Feng, H.L.; Leng, Y.; Ma, C.H.; Zhang, J.; Ren, M.; Chuang, D.M. Combined lithium and valproate treatment delays disease onset, reduces neurological deficits and prolongs survival in an amyotrophic lateral sclerosis mouse model. Neuroscience 2008, 155, 567-572. [CrossRef]

163. Boll, M.C.; Bayliss, L.; Vargas-Cañas, S.; Burgos, J.; Montes, S.; Peñaloza-Solano, G.; Rios, C.; Alcaraz-Zubeldia, M. Clinical and biological changes under treatment with lithium carbonate and valproic acid in sporadic amyotrophic lateral sclerosis. J. Neurol. Sci. 2014, 340, 103-108. [CrossRef]

164. Freeman, L.C.; Ting, J.P. The pathogenic role of the inflammasome in neurodegenerative diseases. J. Neurochem. 2016, 136, 29-38. [CrossRef]

165. Tang, Y.; Le, W. Differential roles of M1 and M2 microglia in neurodegenerative diseases. Mol. Neurobiol. 2016, 53, 1181-1194. [CrossRef] [PubMed]

166. Du, L.; Zhang, Y.; Chen, Y.; Zhu, J.; Yang, Y.; Zhang, H.L. Role of microglia in neurological disorders and their potentials as a therapeutic target. Mol. Neurobiol. 2017, 54, 7567-7584. [CrossRef] [PubMed]

167. Geloso, M.C.; Corvino, V.; Marchese, E.; Serrano, A.; Michetti, F.; D’Ambrosi, N. The dual role of microglia in ALS: Mechanisms and therapeutic approaches. Front. Aging Neurosci. 2017, 9, 242. [CrossRef] [PubMed]

168. Kulczyńska-Przybik, A.; Mroczko, P.; Dulewicz, M.; Mroczko, B. The implication of reticulons (RTNs) in neurodegenerative diseases: From molecular mechanisms to potential diagnostic and therapeutic approaches. Int. J. Mol. Sci. 2021, $22,4630$. [CrossRef]

169. Mizwicki, M.T.; Fiala, M.; Magpantay, L.; Aziz, N.; Sayre, J.; Liu, G.; Siani, A.; Chan, D.; Martinez-Maza, O.; Chattopadhyay, M.; et al. Tocilizumab attenuates inflammation in ALS patients through inhibition of IL6 receptor signaling. Am. J. Neurodegener. Dis. 2012, 1, 305-315.

170. Fiala, M.; Mizwicki, M.T.; Weitzman, R.; Magpantay, L.; Nishimoto, N. Tocilizumab infusion therapy normalizes inflammation in sporadic ALS patients. Am. J. Neurodegener. Dis. 2013, 2, 129-139.

171. Milligan, C.; Atassi, N.; Babu, S.; Barohn, R.J.; Caress, J.B.; Cudkowicz, M.E.; Evora, A.; Hawkins, G.A.; Wosiski-Kuhn, M.; Macklin, E.A.; et al. Tocilizumab is safe and tolerable and reduces $\mathrm{C}$-reactive protein concentrations in the plasma and cerebrospinal fluid of ALS patients. Muscle Nerve 2021, 64, 309-320. [CrossRef]

172. Maier, A.; Deigendesch, N.; Müller, K.; Weishaupt, J.H.; Krannich, A.; Röhle, R.; Meissner, F.; Molawi, K.; Münch, C.; Holm, T.; et al. Interleukin-1 antagonist anakinra in amyotrophic lateral sclerosis-A Pilot Study. PLoS ONE 2015, 10, e0139684. [CrossRef]

173. Kukharsky, M.S.; Skvortsova, V.I.; Bachurin, S.O.; Buchman, V.L. In a search for efficient treatment for amyotrophic lateral sclerosis: Old drugs for new approaches. Med. Res. Rev. 2021, 41, 2804-2822. [CrossRef]

174. Vahsen, B.F.; Gray, E.; Thompson, A.G.; Ansorge, O.; Anthony, D.C.; Cowley, S.A.; Talbot, K.; Turner, M.R. Non-neuronal cells in amyotrophic lateral sclerosis-from pathogenesis to biomarkers. Nat. Rev. Neurol. 2021, 17, 333-348. [CrossRef]

175. Trias, E.; Ibarburu, S.; Barreto-Núñez, R.; Babdor, J.; Maciel, T.T.; Guillo, M.; Gros, L.; Dubreuil, P.; Díaz-Amarilla, P.; Cassina, P.; et al. Post-paralysis tyrosine kinase inhibition with masitinib abrogates neuroinflammation and slows disease progression in inherited amyotrophic lateral sclerosis. J. Neuroinflammation 2016, 13, 177. [CrossRef] [PubMed]

176. Trias, E.; King, P.H.; Si, Y.; Kwon, Y.; Varela, V.; Ibarburu, S.; Kovacs, M.; Moura, I.C.; Beckman, J.S.; Hermine, O.; et al. Mast cells and neutrophils mediate peripheral motor pathway degeneration in ALS. JCI Insight 2018, 3, e123249. [CrossRef] [PubMed]

177. Mora, J.S.; Genge, A.; Chio, A.; Estol, C.J.; Chaverri, D.; Hernández, M.; Marín, S.; Mascias, J.; Rodriguez, G.E.; Povedano, M.; et al. Masitinib as an add-on therapy to riluzole in patients with amyotrophic lateral sclerosis: A randomized clinical trial. Amyotroph. Lateral Scler. Front. Degener. 2020, 21, 5-14. [CrossRef]

178. Chen, Y.; Wang, H.; Ying, Z.; Gao, Q. Ibudilast enhances the clearance of SOD1 and TDP-43 aggregates through TFEB-mediated autophagy and lysosomal biogenesis: The new molecular mechanism of ibudilast and its implication for neuroprotective therapy. Biochem. Biophys. Res. Commun. 2020, 526, 231-238. [CrossRef]

179. Babu, S.; Hightower, B.G.; Chan, J.; Zürcher, N.R.; Kivisäkk, P.; Tseng, C.J.; Sanders, D.L.; Robichaud, A.; Banno, H.; Evora, A.; et al. Ibudilast (MN-166) in amyotrophic lateral sclerosis- An open label, safety and pharmacodynamic trial. Neuroimage Clin. 2021, 30, 102672. [CrossRef]

180. Berry, J.D.; Paganoni, S.; Atassi, N.; Macklin, E.A.; Goyal, N.; Rivner, M.; Simpson, E.; Appel, S.; Grasso, D.L.; Mejia, N.I.; et al. Phase IIa trial of fingolimod for amyotrophic lateral sclerosis demonstrates acceptable acute safety and tolerability. Muscle Nerve 2017, 56, 1077-1084. [CrossRef] [PubMed]

181. Lynch, A.M.; Clevel, M.; Prinjha, R.; Kumar, U.; Stubbs, R.; Wuerthner, J. Non-clinical development of ozanezumab: A humanised antibody targeting the amino terminus of neurite outgrowth inhibitor A (Nogo-A). Toxicol. Res. 2015, 4, 1333. [CrossRef]

182. Jokic, N.; Gonzalez de Aguilar, J.L.; Dimou, L.; Lin, S.; Fergani, A.; Ruegg, M.A.; Schwab, M.E.; Dupuis, L.; Loeffler, J.P. The neurite outgrowth inhibitor Nogo-A promotes denervation in an amyotrophic lateral sclerosis model. EMBO Rep. 2006, 7, 1162-1167. [CrossRef] [PubMed]

183. Scaricamazza, S.; Salvatori, I.; Ferri, A.; Valle, C. Skeletal Muscle in ALS: An unappreciated therapeutic opportunity? Cells 2021, 10, 525. [CrossRef]

184. Meininger, V.; Pradat, P.F.; Corse, A.; Al-Sarraj, S.; Rix Brooks, B.; Caress, J.B.; Cudkowicz, M.; Kolb, S.J.; Lange, D.; Leigh, P.N.; et al. Safety, pharmacokinetic, and functional effects of the Nogo-A monoclonal antibody in amyotrophic lateral sclerosis: A randomized, first-in-human clinical trial. PLoS ONE 2014, 9, e97803. [CrossRef] 
185. Meininger, V.; Genge, A.; van den Berg, L.H.; Robberecht, W.; Ludolph, A.; Chio, A.; Kim, S.H.; Leigh, P.N.; Kiernan, M.C.; Shefner, J.M.; et al. Safety and efficacy of ozanezumab in patients with amyotrophic lateral sclerosis: A randomised, double-blind, placebo-controlled, phase 2 trial. Lancet Neurol. 2017, 16, 208-216. [CrossRef]

186. Koch, J.C.; Kuttler, J.; Maass, F.; Lengenfeld, T.; Zielke, E.; Bähr, M.; Lingor, P. Compassionate use of the ROCK inhibitor fasudil in three patients with amyotrophic lateral sclerosis. Front. Neurol. 2020, 11, 173. [CrossRef]

187. Takata, M.; Tanaka, H.; Kimura, M.; Nagahara, Y.; Tanaka, K.; Kawasaki, K.; Seto, M.; Tsuruma, K.; Shimazawa, M.; Hara, H. Fasudil, a rho kinase inhibitor, limits motor neuron loss in experimental models of amyotrophic lateral sclerosis. Br. J. Pharmacol. 2013, 170, 341-351. [CrossRef] [PubMed]

188. Lingor, P.; Weber, M.; Camu, W.; Friede, T.; Hilgers, R.; Leha, A.; Neuwirth, C.; Günther, R.; Benatar, M.; Kuzma-Kozakiewicz, M.; et al. ROCK-ALS: Protocol for a randomized, placebo-controlled, double-blind phase IIa trial of safety, tolerability and efficacy of the rho kinase (ROCK) inhibitor fasudil in amyotrophic lateral sclerosis. Front. Neurol. 2019, 10, 293. [CrossRef] [PubMed]

189. Wobst, H.J.; Mack, K.L.; Brown, D.G.; Brandon, N.J.; Shorter, J. The clinical trial landscape in amyotrophic lateral sclerosis-Past, present, and future. Med. Res. Rev. 2020, 40, 1352-1384. [CrossRef]

190. Hwee, D.T.; Kennedy, A.; Ryans, J.; Russell, A.J.; Jia, Z.; Hinken, A.C.; Morgans, D.J.; Malik, F.I.; Jasper, J.R. Fast skeletal muscle troponin activator tirasemtiv increases muscle function and performance in the B6SJL-SOD1G93A ALS mouse model. PLoS ONE 2014, 9, e96921. [CrossRef] [PubMed]

191. Shefner, J.M.; Wolff, A.A.; Meng, L.; Bian, A.; Lee, J.; Barragan, D.; Andrews, J.A. BENEFIT-ALS Study Group. A randomized, placebo-controlled, double-blind phase IIb trial evaluating the safety and efficacy of tirasemtiv in patients with amyotrophic lateral sclerosis. Amyotroph. Lateral Scler. Front. Degener. 2016, 17, 426-435. [CrossRef]

192. Andrews, J.A.; Cudkowicz, M.E.; Hardiman, O.; Meng, L.; Bian, A.; Lee, J.; Wolff, A.A.; Malik, F.I.; Shefner, J.M. VITALITY-ALS, a phase III trial of tirasemtiv, a selective fast skeletal muscle troponin activator, as a potential treatment for patients with amyotrophic lateral sclerosis: Study design and baseline characteristics. Amyotroph. Lateral Scler. Front. Degener. 2018, 19, 259-266. [CrossRef]

193. Shefner, J.M.; Andrews, J.A.; Genge, A.; Jackson, C.; Lechtzin, N.; Miller, T.M.; Cockroft, B.M.; Meng, L.; Wei, J.; Wolff, A.A.; et al. A phase 2, double-blind, randomized, dose-ranging trial of reldesemtiv in patients with ALS. Amyotroph. Lateral Scler. Front. Degener. 2021, 22, 287-299. [CrossRef]

194. MacGowan, D.J.; Scelsa, S.N.; Imperato, T.E.; Liu, K.N.; Baron, P.; Polsky, B. A controlled study of reverse transcriptase in serum and CSF of HIV-negative patients with ALS. Neurology 2007, 68, 1944-1946. [CrossRef] [PubMed]

195. McCormick, A.L.; Brown, R.H., Jr.; Cudkowicz, M.E.; Al-Chalabi, A.; Garson, J.A. Quantification of reverse transcriptase in ALS and elimination of a novel retroviral candidate. Neurology 2008, 70, 278-283. [CrossRef] [PubMed]

196. Douville, R.; Liu, J.; Rothstein, J.; Nath, A. Identification of active loci of a human endogenous retrovirus in neurons of patients with amyotrophic lateral sclerosis. Ann. Neurol. 2011, 69, 141-151. [CrossRef]

197. Castanedo-Vazquez, D.; Bosque-Varela, P.; Sainz-Pelayo, A.; Riancho, J. Infectious agents and amyotrophic lateral sclerosis: Another piece of the puzzle of motor neuron degeneration. J. Neurol. 2019, 266, 27-36. [CrossRef] [PubMed]

198. Gold, J.; Rowe, D.B.; Kiernan, M.C.; Vucic, S.; Mathers, S.; van Eijk, R.P.A.; Nath, A.; Garcia Montojo, M.; Norato, G.; Santamaria, U.A.; et al. Safety and tolerability of Triumeq in amyotrophic lateral sclerosis: The lighthouse trial. Amyotroph. Lateral Scler. Front. Degener. 2019, 20, 595-604. [CrossRef] [PubMed]

199. Nagtegaal, I.D.; Lakke, E.A.; Marani, E. Trophic and tropic factors in the development of the central nervous system. Arch. Physiol. Biochem. 1998, 106, 161-202. [CrossRef] [PubMed]

200. Zinman, L.; Cudkowicz, M. Emerging targets and treatments in amyotrophic lateral sclerosis. Lancet Neurol. 2011, 10, 481-490. [CrossRef]

201. Nagel, G.; Peter, R.S.; Rosenbohm, A.; Koenig, W.; Dupuis, L.; Rothenbacher, D.; Ludolph, A.C. Association of Insulin-like Growth Factor 1 Concentrations with Risk for and Prognosis of Amyotrophic Lateral Sclerosis-Results from the ALS Registry Swabia. Sci. Rep. 2020, 10, 736. [CrossRef]

202. Azzouz, M.; Ralph, G.S.; Storkebaum, E.; Walmsley, L.E.; Mitrophanous, K.A.; Kingsman, S.M.; Carmeliet, P.; Mazarakis, N.D. VEGF delivery with retrogradely transported lentivector prolongs survival in a mouse ALS model. Nature 2004, 429, 413-417. [CrossRef]

203. Sun, W.; Funakoshi, H.; Nakamura, T. Overexpression of HGF retards disease progression and prolongs life span in a transgenic mouse model of ALS. J. Neurosci. 2002, 22, 6537-6548. [CrossRef]

204. Kitamura, K.; Nagoshi, N.; Tsuji, O.; Matsumoto, M.; Okano, H.; Nakamura, M. Application of hepatocyte growth factor for acute spinal cord injury: The road from basic studies to human treatment. Int. J. Mol. Sci. 2019, 20, 1054. [CrossRef]

205. Le Pichon, C.E.; Dominguez, S.L.; Solanoy, H.; Ngu, H.; Lewin-Koh, N.; Chen, M.; Eastham-Anderson, J.; Watts, R.; Scearce-Levie, K. EGFR inhibitor erlotinib delays disease progression but does not extend survival in the SOD1 mouse model of ALS. PLoS ONE 2013, 8, e62342. [CrossRef]

206. Chen, T.; Benmohamed, R.; Arvanites, A.C.; Ralay Ranaivo, H.; Morimoto, R.I.; Ferrante, R.J.; Watterson, D.M.; Kirsch, D.R.; Silverman, R.B. Arylsulfanyl pyrazolones block mutant SOD1-G93A aggregation. Potential application for the treatment of amyotrophic lateral sclerosis. Bioorg. Med. Chem. 2011, 19, 613-622. [CrossRef] [PubMed] 
207. Neymotin, A.; Calingasan, N.Y.; Wille, E.; Naseri, N.; Petri, S.; Damiano, M.; Liby, K.T.; Risingsong, R.; Sporn, M.; Beal, M.F.; et al. Neuroprotective effect of Nrf2/ARE activators, CDDO ethylamide and CDDO trifluoroethylamide, in a mouse model of amyotrophic lateral sclerosis. Free Radic. Biol. Med. 2011, 51, 88-96. [CrossRef]

208. Zhang, W.; Benmohamed, R.; Arvanites, A.C.; Morimoto, R.I.; Ferrante, R.J.; Kirsch, D.R.; Silverman, R.B. Cyclohexane 1,3-diones and their inhibition of mutant SOD1-dependent protein aggregation and toxicity in PC12 cells. Bioorg. Med. Chem. 2012, 20, 1029-1045. [CrossRef] [PubMed]

209. Ahn, S.W.; Jeon, G.S.; Kim, M.J.; Shon, J.H.; Kim, J.E.; Shin, J.Y.; Kim, S.M.; Kim, S.H.; Ye, I.H.; Lee, K.W.; et al. Neuroprotective effects of JGK-263 in transgenic SOD1-G93A mice of amyotrophic lateral sclerosis. J. Neurol. Sci. 2014, 340, 112-116. [CrossRef] [PubMed]

210. Tanaka, K.; Kanno, T.; Yanagisawa, Y.; Yasutake, K.; Inoue, S.; Hirayama, N.; Ikeda, J.E. A novel acylaminoimidazole derivative, WN1316, alleviates disease progression via suppression of glial inflammation in ALS mouse model. PLoS ONE 2014, 9, e87728. [CrossRef] [PubMed]

211. Getter, T.; Zaks, I.; Barhum, Y.; Ben-Zur, T.; Böselt, S.; Gregoire, S.; Viskind, O.; Shani, T.; Gottlieb, H.; Green, O.; et al. A chemical chaperone-based drug candidate is effective in a mouse model of amyotrophic lateral sclerosis (ALS). ChemMedChem 2015, 10, 850-861. [CrossRef] 